\title{
Persistent Cytomegalovirus Infection in Amniotic Membranes of the Human Placenta
}

\author{
Takako Tabata, Matthew Petitt, June Fang-Hoover, Martin Zydek, and Lenore Pereira
}

From the Department of Cell and Tissue Biology, School of Dentistry, University of California, San Francisco, San Francisco, California

\author{
Accepted for publication \\ July 14, 2016. \\ Address correspondence to \\ Lenore Pereira, Ph.D., \\ University of California, \\ San Francisco, 513 Parnassus \\ Ave, San Francisco, \\ CA 94143. E-mail: lenore. \\ pereira@ucsf.edu.
}

\begin{abstract}
Human cytomegalovirus (HCMV) is the leading viral cause of birth defects, including microcephaly, neurological deficits, hearing impairment, and vision loss. We previously reported that epithelial cells in amniotic membranes of placentas from newborns with intrauterine growth restriction and underlying congenital HCMV infection contain viral proteins in cytoplasmic vesicles. Herein, we immunostained amniotic membranes from 51 placentas from symptomatic and asymptomatic congenital infection with HCMV DNA in amniotic fluid and/or newborn saliva, intrauterine growth restriction, preterm deliveries, and controls. We consistently observed HCMV proteins in amniotic epithelial cells (AmEpCs) from infected placentas, sometimes with aberrant morphology. Primary AmEpCs isolated from mid-gestation placentas infected with pathogenic VR1814 proliferated and released infectious progeny for weeks, producing higher virus titers than late-gestation cells that varied by donor. In contrast to intact virion assembly compartments in differentiated retinal pigment epithelial cells, infected AmEpCs made dispersed multivesicular bodies. Primary AmEpCs and explants of amniochorionic membranes from midgestation placentas formed foci of infection, and interferon- $\beta$ production was prolonged. Infected AmEpCs up-regulated anti-apoptotic proteins survivin and $\mathrm{BCl}-\mathrm{x}_{\mathrm{L}}$ by mechanisms dependent and independent of the activated STAT3. Amniotic membranes naturally expressed both survivin and $\mathrm{Bcl}-\mathrm{x}_{\mathrm{L}}$, indicating that fetal membranes could foster persistent viral infection. Our results suggest strengthening innate immune responses and reducing viral functions could suppress HCMV infection in the fetal compartment. (Am J Pathol 2016, 186: 2970-2986; http://dx.doi.org/10.1016/j.ajpath.2016.07.016)
\end{abstract}

Human cytomegalovirus (HCMV) is the most common infectious cause of permanent birth defects. It is estimated that each year approximately 40,000 infants are born with congenital HCMV infection, 400 will succumb in childhood and 8000 will have permanent disabilities, which include microcephaly, severe neurological deficiencies, and hearing and vision loss. ${ }^{1,2}$ More birth defects result from congenital HCMV infection than from other, better known conditions, including Down syndrome, fetal alcohol syndrome, and neural tube defects. ${ }^{3,4}$ Placental pathology occurs predominantly in primary maternal infection with virus transmission and includes avascular villi, knotting of the syncytiotrophoblast surface, and edema that reduces the exchange between maternal and fetal circulation, resulting in a hypoxic environment. ${ }^{5,6}$ Hyperimmune globulin treatment enables compensatory development of syncytiotrophoblast covering the villus surface perfused by maternal blood. ${ }^{5-7}$ Structural defects in the developing placenta can lead to intrauterine growth restriction (IUGR) with or without transmission. ${ }^{6}$ Despite the importance of congenital infection as a cause of fetal morbidity, our understanding of the cellular and molecular changes in the placenta and fetal membranes is rudimentary.

HCMV spreads from foci of infected cytotrophoblasts in chorionic villi to fetal blood vessels in the villus core. ${ }^{8}$ Primary maternal infection in the first and second trimester carries a $30 \%$ to $38 \%$ rate of transmission and the greatest risk of disease, ${ }^{9,10}$ whereas babies infected in the third trimester $(72 \%)$ are usually asymptomatic, ${ }^{9}$ but

Supported by NIH Institute of Allergy and Infectious Diseases grants RO1AI046657 and R56AI101130 (L.P.) and Eunice Kennedy Shriver National Institute of Child Health and Human Development grant R21HD061890 (T.T.), the University of California, San Francisco California Preterm Birth Initiative grant (T.T.), and a Deutsche Forschungsgemeinschaft postdoctoral fellowship DFG ZY110/1 (M.Z.).

Disclosures: None declared. 
progressive hearing loss can occur. ${ }^{11,12}$ Diagnosis of virus transmission entails detection of HCMV DNA; however, high viral load in amniotic fluid does not correlate with poor outcome. $^{13-17}$

In contrast to the vascular chorionic membrane,${ }^{18}$ the amniotic membrane is an avascular structure lined with epithelial cells bathed in amniotic fluid that surrounds the fetus. ${ }^{19}$ As the first line of defense against pathogens that invade the fetal compartment, amniotic epithelial cells (AmEpCs) function as a biological barrier that has antimicrobial and antiviral properties, as well as stem cell properties. $^{20-22}$ The amniotic epithelium secretes soluble factors and cytokines that modulate innate and adaptive immune responses. ${ }^{23,24}$ IL-6 and IL-8 have been found in high concentrations in amniotic fluid at term, and the expression of these inflammatory cytokines is increased in the presence of IL- $1 \beta$, tumor necrosis factor- $\alpha$, and bacterial lipopolysaccharide. ${ }^{25}$ Elevated IL-6 in amniotic fluid is a risk factor for spontaneous early delivery ( $<32$ weeks) and late preterm delivery ( $>32$ weeks), but some patients with intra-amniotic inflammation deliver at term. ${ }^{26}$ Analysis of amniotic fluid from cases of congenital HCMV infection showed elevated levels of inflammatory cytokines and chemokines, suggesting inflammatory responses could contribute to pathology. ${ }^{27}$

We recently reported that epithelial cells in amniotic membranes from pregnancies complicated by congenital HCMV infection and IUGR contain viral proteins in large cytoplasmic vesicles. ${ }^{6}$ Herein, we examined 51 placentas from deliveries that included congenital infection diagnosed by the detection of viral DNA in amniotic fluid and/or newborn saliva, idiopathic preterm deliveries, IUGR, and gestational age-matched controls. In accord with the detection of viral DNA, we consistently observed HCMV proteins in AmEpCs. Studies of primary AmEpCs isolated from mid-gestation placentas infected with pathogenic VR1814 showed that infected cells proliferated and released progeny for weeks and that higher titers were produced in these cells than in late-gestation cells and varied by donor. In contrast to a virion assembly compartment made in differentiated retinal pigment epithelial cells, infected AmEpCs made dispersed multivesicular bodies. Infected AmEpCs produced interferon (IFN)- $\beta$ over a prolonged period and the anti-apoptotic proteins survivin and $\mathrm{Bcl}-\mathrm{x}_{\mathrm{L}}$ via mechanisms dependent and independent, respectively, of the activated STAT3. Amniotic membranes naturally expressed both survivin and Bcl- $\mathrm{x}_{\mathrm{L}}$, indicating an environment that could foster persistent viral infection. Our results suggest that strengthening innate immune responses and reducing viral functions could suppress HCMV infection in the fetal compartment. Furthermore, as we recently reported that AmEpCs are highly infectable by Zika virus, ${ }^{28}$ another viral cause of serious neurological defects in developing fetuses, our results may point to a common mechanism of vertical viral transmission and pathogenesis in pregnancy that could be therapeutically targeted by common strategies.

\section{Materials and Methods}

\section{Human Placentas and Blood and Saliva Samples}

\section{Placentas}

The University of California's Committee on Human Research and Institutional Review Board approved this study. Protocols involved deliveries at term at University of California, San Francisco Mission Bay Hospital (San Francisco, CA; 36 placentas received from 35 donors). Biopsy specimens (one central and two to four peripheral) and amniotic membranes were fixed in 10\% formalin (24 to 48 hours), embedded in paraffin, and sectioned for immunohistochemical and histological analysis. ${ }^{6}$ Placental biopsy specimens from three diagnosed cases of congenital infection were obtained from the CMV Registry and one from the standing collection of the Department of Pathology at the University of California, San Francisco. Biopsy specimens from Cedars Sinai Medical Center (Los Angeles, CA) (11 total) were published previously. ${ }^{6}$ Primary AmEpCs were isolated from amniotic membranes of placentas after elective terminations at University of California, San Francisco hospitals and are described separately below.

\section{Blood and Newborn Saliva Samples}

Along with placentas, maternal and cord blood samples (14 donor samples analyzed) (Table 1) and newborn saliva $(n=6)$ (Table 1) were collected at delivery when possible. Blood was collected in purple-top tubes containing EDTA and centrifuged to obtain plasma for analysis. Saliva samples were taken from newborns in the delivery room by a physician or nurse using sterile cotton-tipped swabs. Swabs were immediately placed in virus transport medium. After incubation in the collection solution overnight at $4^{\circ} \mathrm{C}$, the solution was removed from the tubes and stored at $-80^{\circ} \mathrm{C}$.

\section{Cell Culture, Explants, and Infection}

AmEpCs were isolated from mid-gestation (17 to 23.6 weeks; $n=17$ ) and late gestation (29.3 to 39.3 weeks; $n=4$ ) placentas and cultured according to published methods ${ }^{29}$ with the following modifications: isolated AmEpCs were cultured on fibronectin-coated plates in Dulbecco's modified Eagle's medium/F12 supplemented with $20 \mathrm{ng} / \mathrm{mL}$ epidermal growth factor (R\&D Systems, Minneapolis, MN), 10\% fetal bovine serum, $1 \%$ nonessential amino acids, $55 \mu \mathrm{mol} / \mathrm{L} \quad 2-$ mercaptoethanol (Gibco, Thermo Fisher Scientific, Waltham, MA), antibiotics, and antimycotics (University of California, San Francisco Cell Culture Facility). AmEpCs positive for cytokeratin 19 and negative for HCMV proteins by immunostaining were used for experiments. Primary AmEpCs (passage 0 to 2 ) were infected with VR1814, a pathogenic clinical strain $^{30}$ at a multiplicity of infection of 3. In some experiments, TB40/E-derived parental virus (vBAC4-luc), $\Delta 131 \mathrm{~A}$ mutant (vBAC4-luc/UL131 Astop) $^{31}$ (gift from Dr. Barber Adler, Max von Pettenkofer-Institute for Virology, Munich, Germany), and CMV Registry 169, an attenuated laboratory strain 
Table 1 Placentas and Blood Samples Used in This Study

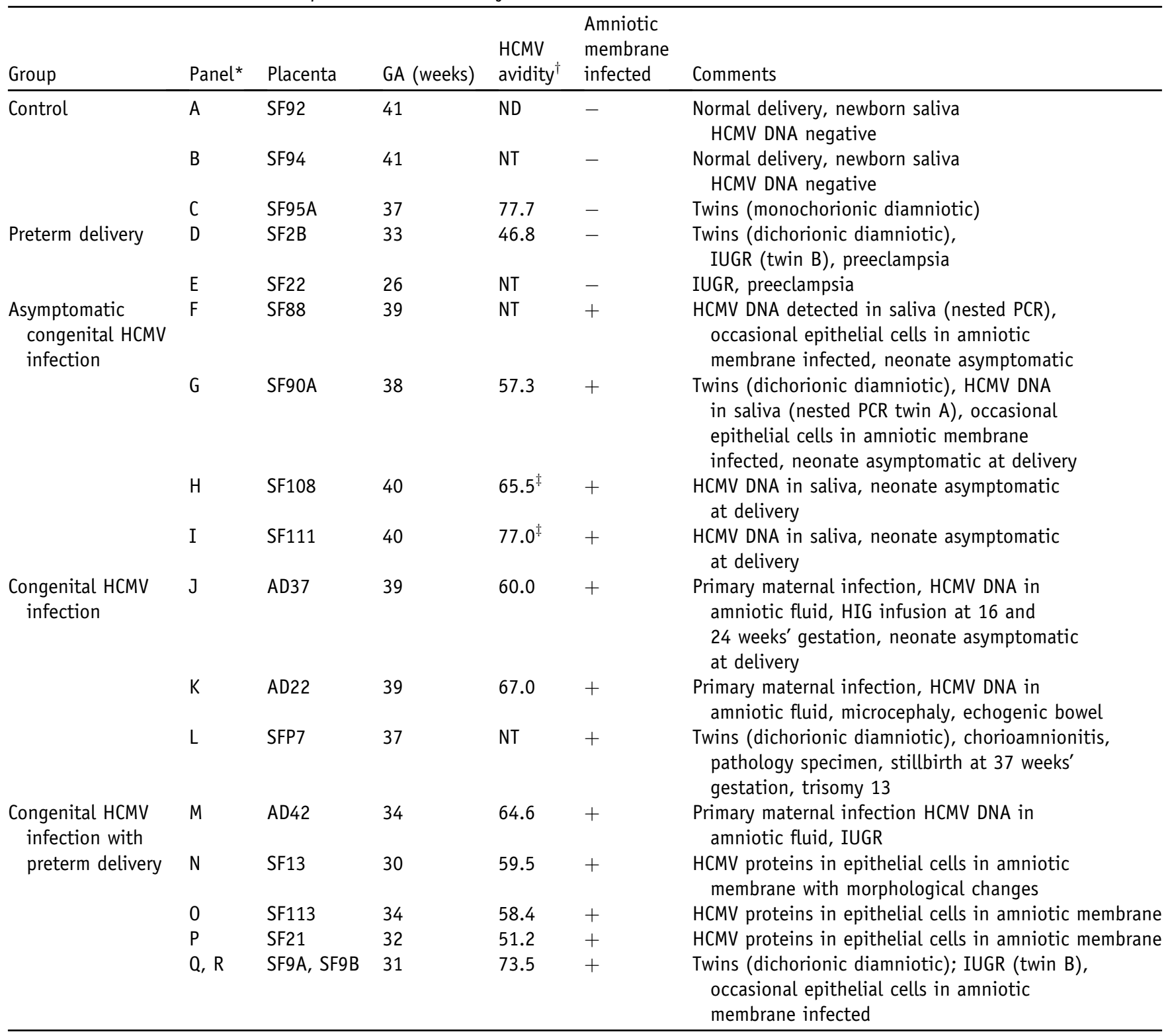

*Letters correlate with the panel letters in Figure 1.

${ }^{\dagger}$ Maternal blood plasma at delivery.

${ }^{\ddagger}$ Cord blood plasma.

AD, CMV Registry; GA, gestational age; HCMV, human cytomegalovirus; HIG, hyperimmune globulin; IUGR, intrauterine growth restriction; ND, not detected; NT, not tested; SF, University of California, San Francisco Mission Bay Hospital; SFP, Department of Pathology at the University of California, San Francisco; + , present; -, absent.

passaged in human foreskin fibroblasts, were used. For preparation of amniochorionic explants $(n=3)$, membranes were dissected from placentas at 14 to 18 weeks' gestation and plated on Millicell-CM inserts (0.4- $\mu \mathrm{m}$ pore size; Millipore, Billerica, MA) coated with Matrigel (BD Biosciences, San Jose, CA) in culture medium without epidermal growth factor, with the apical surface of the amniotic membrane upward and chorion downward. Thus, trophoblasts from the chorion invaded the Matrigel and anchored the composite membrane, simulating the in vivo context. After 12 to 18 hours, explants were infected $\left(3 \times 10^{6}\right.$ plaque-forming units per explant) with VR1814.
Explants were maintained for 7 days after infection and fixed in 4\% paraformaldehyde (Wako Chemicals USA, Richmond, VA) for histological analysis. ARPE-19 cells were grown in Dulbecco's modified Eagle's medium (Gibco) supplemented with $10 \%$ fetal bovine serum and infected with VR1814 at a multiplicity of infection of 0.1 .

\section{Serological and Other Reagents}

The following antibodies were purchased: rabbit polyclonal antibodies to Oct4, Hand1, Ki-67, and STAT1, goat 
polyclonal anti-GATA3 and mouse monoclonal antibodies (MAbs) to phospho-STAT1 (Y701) and CD63 (Abcam, Cambridge, UK); rabbit MAbs to survivin, STAT3, phospho-STAT3 (Y705), phospho-interferon regulatory factor (IRF) 7 (S471/472), and phospho-IRF3 (S396) (Cell Signaling Technology, Danvers, MA); rabbit polyclonal antibodies to cytokeratin 19, SOX2, and Bcl- $\mathrm{x}_{\mathrm{L}}$ (Proteintech, Chicago, IL); rabbit polyclonal anti-IRF-7 and a mouse MAb to anti-Bcl-2 (Santa Cruz Biotechnology, Dallas, TX); a mouse MAb to stage-specific embryonic antigen-4 and an anti-HCMV MAb blend (MAB8121, cocktail of clones 8B1.2, IG5.2, and 2D4.2), which reacts with immediate early (IE), early, and late antigen preparations (Merck Millipore, Billerica, MA); and an anti-actin mouse MAb (Sigma-Aldrich, St. Louis, MO). The following MAbs to HCMV infected cell proteins, generated by the Pereira laboratory, ${ }^{32,33}$ were also used: $\mathrm{CH} 112-2$ to glycoprotein B (UL55); CH19 to pp28 (UL99); CH160 to IE nuclear proteins (IE1 and IE2, UL122 and UL123) for immunoblotting; CH443 to IE1 (UL123) for immunofluorescence staining; and $\mathrm{CH} 12$ to pp65 (UL83). Guinea pig anti-HCMV gB was a gift from Chiron Corp. (Emeryville, CA). The STAT3 inhibitors S31-201, WP1006, and STA21 were purchased from Santa Cruz Biotechnology.

\section{Immunohistochemical Staining}

Serial sections ( $5 \mu \mathrm{m}$ thick) were either stained with hematoxylin and eosin or immunostained. ${ }^{6}$ Three to six biopsy specimens and at least three sections containing representative amniochorionic membranes were examined for HCMV proteins. Antigen retrieval was performed for each protein as described below, followed by blocking with $1.2 \%$ normal serum from the same species as the secondary antibody. Sections were incubated with primary antibody for 2 to 3 hours at room temperature or overnight at $4{ }^{\circ} \mathrm{C}$, washed, and processed for color development using Vectastain avidin-biotin complex horseradish peroxidase kit (mouse or rabbit; Vector Laboratories, Burlingame, CA), according to the manufacturer's instructions, followed by color development with a diaminobenzidine substrate kit (Abcam). Slides were counterstained with hematoxylin (Sigma-Aldrich), dehydrated, and mounted using Vectamount AQ (Vector Laboratories). Antibodies used for immunohistochemistry were as follows: mouse MAb anti-HCMV blend, rabbit MAb anti-survivin, and rabbit polyclonal anti-Bcl- $\mathrm{x}_{\mathrm{L}}$. Isotype control for survivin immunostaining was rabbit MAb to cleaved caspase 3 (Cell Signaling Technology) and for Bcl- $\mathrm{x}_{\mathrm{L}}$ was rabbit polyclonal antibody to LYVE1 (Abcam). Antigen retrieval was performed for each antibody as follows: HCMV infected cell proteins, sections were incubated with $0.4 \%$ pepsin (SigmaAldrich) in $0.01 \mathrm{~N} \mathrm{HCl}\left(30\right.$ minutes, $\left.37^{\circ} \mathrm{C}\right)$; survivin and control slides were heat treated in $10 \mathrm{mmol} / \mathrm{L}$ sodium citrate, pH 6.0, in a 2100 Retriever pressure cooker (Diatome, Electron Microscopy Sciences, Hatfield, PA) using its automated pressurized heat cycle (approximately 15 minutes) and cooled for 2 hours; $\mathrm{Bcl}-\mathrm{x}_{\mathrm{L}}$ and control slides were heat treated in 10 $\mathrm{mmol} / \mathrm{L}$ Tris (pH 9.0), $1 \mathrm{mmol} / \mathrm{L}$ EDTA. Images were taken on a Nikon TS100 inverted microscope equipped with a Nikon DS-F12 camera controlled by Nikon NIS-Elements software version F4.00.00 (Nikon Instruments, Inc., Melville, NY).

\section{Immunofluorescence Staining}

Cells grown on coverslips were fixed with $4 \%$ paraformaldehyde and permeabilized with $0.1 \%$ Triton X-100 or ice-cold methanol. Nonspecific antibody binding to the viral Fc receptor was blocked using normal human serum. ${ }^{34}$ For double immunostaining, cells were simultaneously incubated with primary antibodies from different species and secondary antibodies labeled with fluorescein isothiocyanate or rhodamine red-X. Nuclei were stained with DAPI (Vector Laboratories). Alternatively, the coverslips were incubated with primary antibodies against cellular proteins overnight, followed by incubation with secondary antibodies, then stained with antibodies to HCMV proteins. Images were obtained using a Nikon Eclipse 50i microscope equipped with a SPOT 7.4 Slider camera (Diagnostic Instruments, Sterling, MI) controlled by SPOT 2.0 Advanced software.

\section{Immunoblot Analysis}

Cells were lysed in radioimmunoprecipitation assay buffer containing a protease inhibitor cocktail (Thermo Fisher Scientific) and clarified by centrifugation. Proteins were separated by SDS-PAGE, transferred to Hybond membranes (GE Healthcare Life Sciences, Pittsburgh, PA), and blocked for 2 hours in phosphate-buffered saline containing 5\% skim milk and $0.05 \%$ Tween-20. After incubation with primary antibody for 16 hours at $4{ }^{\circ} \mathrm{C}$, then with peroxidase-conjugated secondary antibody for 1 hour, blots were developed with WesternBright ECL or Quantum horseradish peroxidase substrate (Advansta, Menlo Park, CA).

\section{Virus Titration}

Infectious progeny in conditioned media from infected AmEpCs were quantified in human foreskin fibroblasts and AmEpCs (23.5 weeks' gestation) with a rapid immunofluorescence-based infectivity assay. ${ }^{35}$ Quantification of virus titers from 17 to 32 weeks' gestation AmEpCs was done in parallel.

\section{Virus Neutralization Assays}

HCMV neutralizing assays were performed as described. ${ }^{36,37}$ Viral titers were adjusted to give a total of 600 to 800 IE1-positive cells/well in 24-well plates. Human MAbs to the pentamer component UL130/131A (TLR310, 1F11) and gB (TRL345), hyperimmune globulin (Cytotect), and negative control MAb Synagis were gifts from Trellis Bioscience (Menlo Park, CA). 


\section{ELISA}

Levels of IL- 6 , IFN- $\alpha$, and IFN- $\beta$ in conditioned media were measured using a commercial sandwich enzymelinked immunosorbent assay [ELISA; Quantikine IL-6 immunoassay (R\&D Systems), VeriKine-Human IFN- $\alpha$ ELISA kit and VeriKine-HS Human IFN- $\beta$ serum ELISA kit (PBL Assay Science, Piscataway Township, NJ)], according to the manufacturer's instructions.

\section{IgG Avidity Assays}

Anti-HCMV IgG avidity was measured using the Serion ELISA Classic CMV Avidity Reagent and the Serion ELISA Classic CMV IgG kit (Institut Virion/Serion GmbH, Würzburg, Germany), according to the manufacturer's instructions.

\section{PCR for HCMV DNA}

PCR analysis for HCMV DNA in saliva and amniotic fluid samples was performed as follows. Each reaction contained $17.9 \mu \mathrm{L}$ RNase-free water, $2.5 \mu \mathrm{L}$ Coraload PCR buffer (Qiagen, Germantown, MD), $0.5 \mu \mathrm{L}$ dNTP mix $(2.5 \mathrm{mmol} /$ $\mathrm{L}$ each), $0.125 \mu \mathrm{L}$ HotStarTaq Plus DNA polymerase (Qiagen), $0.75 \mu \mathrm{L}$ each of $10 \mu \mathrm{mol} / \mathrm{L}$ forward and $10 \mu \mathrm{mol} /$ $\mathrm{L}$ reverse primers (forward $=5^{\prime}$-GGTCACTAGTGACGCTTGTATGATGA- ${ }^{\prime}$; reverse $=5^{\prime}$-GATAGTCGCGGGTACAGGGGACTCT- $3^{\prime}$ ), and $2.5 \mu \mathrm{L}$ saliva collection fluid or amniotic fluid, undiluted. PCR was performed in a BioRad T100 Thermal Cycler using the following temperature regimen: i) $95^{\circ} \mathrm{C}, 5$ minutes; ii) 35 cycles of $94^{\circ} \mathrm{C}$ for 45 seconds, $56^{\circ} \mathrm{C}$ for 45 seconds, and $72^{\circ} \mathrm{C}$ for 60 seconds; and iii) $72^{\circ} \mathrm{C}$ for 10 minutes. A second, nested PCR was performed using the same conditions with $1 \mu \mathrm{L}$ from the first reaction, 25 amplification cycles, and internal primers (forward $=5^{\prime}$-AAGTGAGTTCTGTCGGGTGCT$3^{\prime}$; reverse $=5^{\prime}$-GTGACACCAGAGAATCAGAGGA- $3^{\prime}$ ). Positive control HCMV IE1 DNA plasmid was included at 1 and $10 \mathrm{ng}$ per reaction. Water was used as a negative control. PCR products were analyzed by agarose gel electrophoresis.

\section{Results}

HCMV Proteins Detected in Amniotic Membranes of Placentas from Primary and Recurrent Congenital Infection

We recently reported the detection of HCMV proteins in cytoplasmic vesicles in epithelial cells of amniotic membranes from pregnancies complicated by IUGR and underlying congenital infection. ${ }^{6}$ Figure 1 shows amniotic membranes in placentas immunostained for HCMV proteins from cases of congenital infection, diagnosed during pregnancy by detection of HCMV DNA in amniotic fluid at mid-gestation or in newborn saliva at delivery, idiopathic preterm deliveries, and gestation-matched controls. Thirtythree placentas from 32 deliveries were studied for the presence of HCMV proteins in amniotic epithelium, and detailed analysis of 18 of these placentas with matching blood and saliva samples, where available, is summarized in Table 1. Cases were organized into five groups according to the presence or absence of HCMV proteins in amniotic membranes and whether delivery was preterm or symptomatic infection. Figure 1 includes the following: controls (Figure 1, A-C) and preterm deliveries negative for viral proteins (Figure 1, D and E); asymptomatic infection with HCMV proteins in amniotic membranes (Figure 1, F-I); congenital infection (Figure 1, J-L); and congenital infection with preterm delivery (Figure 1, M-R) and IUGR (Figure 1, M and R). In symptomatic infection, epithelial cells in amniotic membranes were irregular, cell-cell junctions were lost, and cell fusion and blebbing occurred (Figure 1, K, M, N, and Q). Asymptomatic deliveries included primary maternal infection with hyperimmune globulin treatment at 16 and 24 weeks' gestation (Figure 1J).

Because avidity increases during pregnancy, we could not determine whether primary or recurrent maternal infection had occurred. ${ }^{38-40}$ Controls were seronegative or seropositive with high IgG avidity (Table 1), one preterm delivery had moderate avidity, and three asymptomatic deliveries had high avidity IgG, especially in cord sera (Table 1), as previously reported. ${ }^{36}$ In cases of congenital infection diagnosed during pregnancy by detection of HCMV DNA in amniotic fluid, avidity values were high (Table 1). Others diagnosed at delivery had moderately high avidities (Table 1). Finally, a twin delivery with high avidity and focal infection in the amniotic membrane suggested recurrence (Table 1).

To determine whether infected amniotic membranes correlated with virus transmission, samples of saliva were tested for HCMV DNA by PCR to diagnose congenital infection, a method reportedly as sensitive and specific as urine cultures. $^{41-43}$ Six saliva samples were tested, including two from controls (Figure 1, A and B) and four from babies with viral proteins in amniotic membranes (Figure 1, F-I). In addition, the presence of HCMV DNA in amniotic fluid was confirmed in samples previously tested by clinical laboratories (Table 1). These results showed that HCMV proteins are present in the amniotic epithelium in diagnosed cases of congenital infection (Figure 1 and Table 1) and deliveries with HCMV DNA in saliva (Figure 1 and Table 1).

\section{Persistent HCMV Infection in Primary AmEpCs in Vitro}

The presence of viral proteins in confirmed cases of symptomatic congenital HCMV infection suggested virus replication in these cells in utero. To determine whether HCMV infects AmEpCs, primary cells isolated from mid-gestation and late gestation placentas were infected with VR1814. Immunostaining of control 


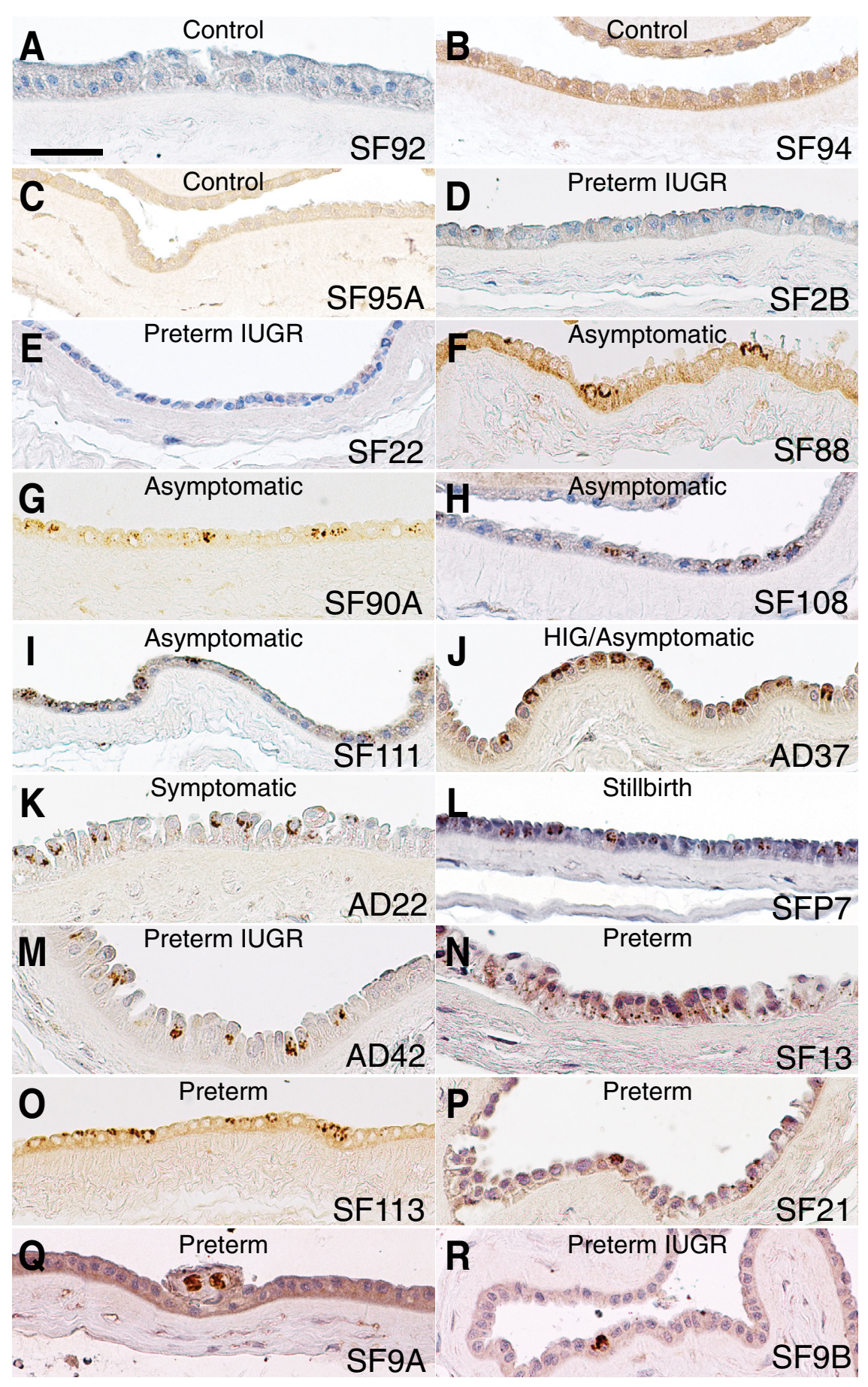

Figure 1 Immunohistochemical staining for human cytomegalovirus (HCMV)-infected cell proteins in amniotic membranes from placentas at delivery (additional information available in Table 1). Sample designations and sources are described in Materials and Methods. A-C: Uninfected controls. D and E: Uninfected amniotic membranes from preterm deliveries with intrauterine growth restriction (IUGR). F-I: Infected amniotic membranes from asymptomatic term deliveries and detection of HCMV DNA in newborn saliva. J-L: Infected amniotic membranes from diagnosed primary maternal HCMV infection. $\mathbf{J}$ and K: HCMV DNA in amniotic fluid. L: Congenital infection and stillbirth. M-R: HCMV-infected amniotic membranes from preterm deliveries. M: Diagnosed primary maternal infection with HCMV DNA in amniotic fluid. Scale bar $=50 \mu \mathrm{m}$. HIG, hyperimmune globulin.

AmEpCs, which have the properties of fetal stem cells, ${ }^{22,29,44}$ revealed expression of the pluripotency proteins Oct4 and SOX2, the embryonic stem cellspecific surface antigen stage-specific embryonic antigen- $4,{ }^{45}$ and the transcription factors GATA-3 and Hand-1, regulators of cell differentiation ${ }^{44}$ (Figure 2A). Late in infection, when $\mathrm{gB}$ and $\mathrm{pp} 28$ were expressed, Oct4, SOX2, stage-specific embryonic antigen-4, GATA3, and Hand1 were down-regulated (Figure 2A).
In some cells, GATA3 and Hand1 relocated to perinuclear vesicles and partially overlapped viral protein pp28.

Next, the levels of VR1814 infection in mid-gestation and late gestation AmEpCs were quantified in several assays and compared with ARPE-19, highly differentiated retinal pigment epithelial cells used in studies of lytic HCMV infection. ${ }^{46-52}$ Immunoblot analysis confirmed that infected AmEpCs from mid-gestation (17 weeks) and late gestation (39 weeks) 

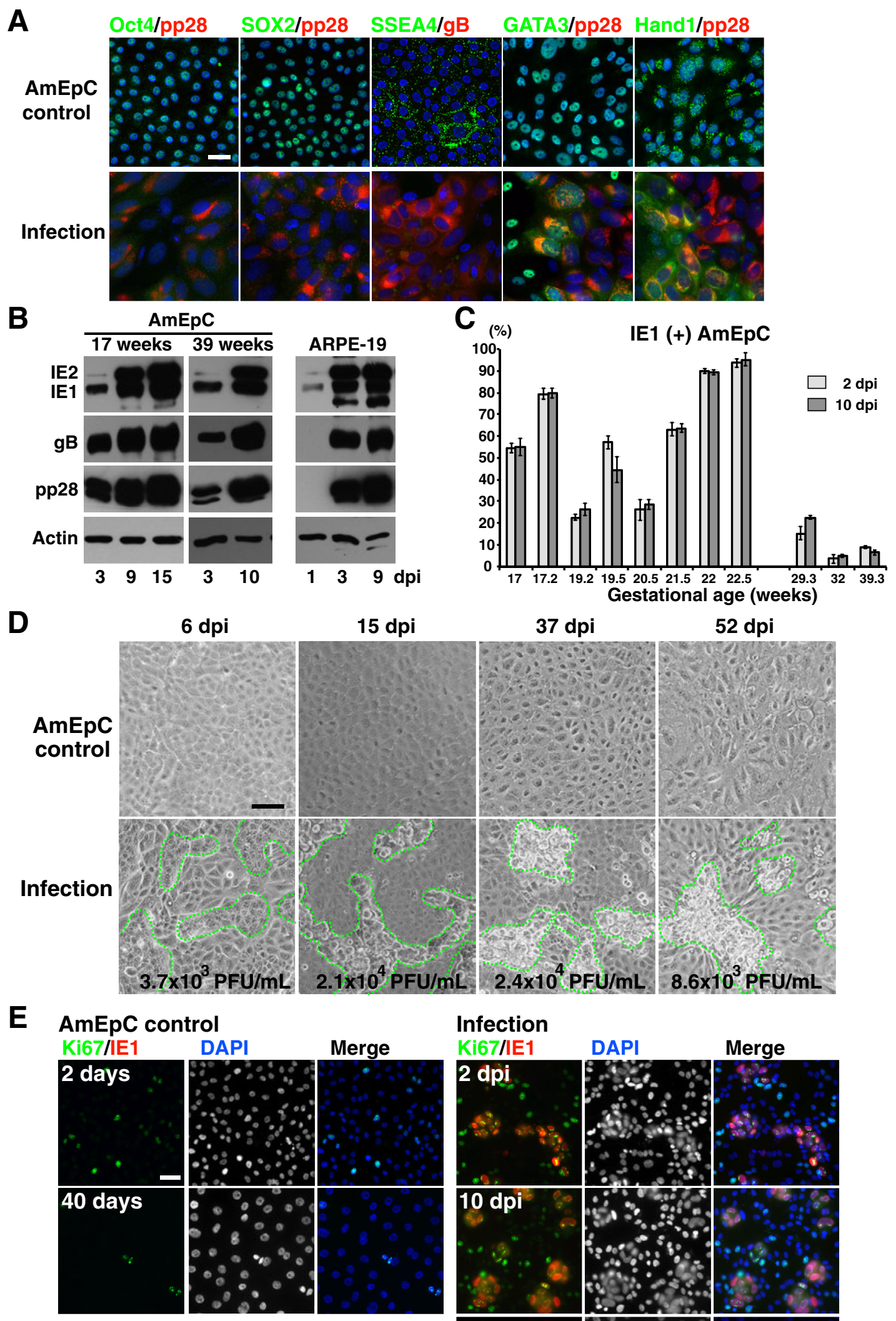

Infection

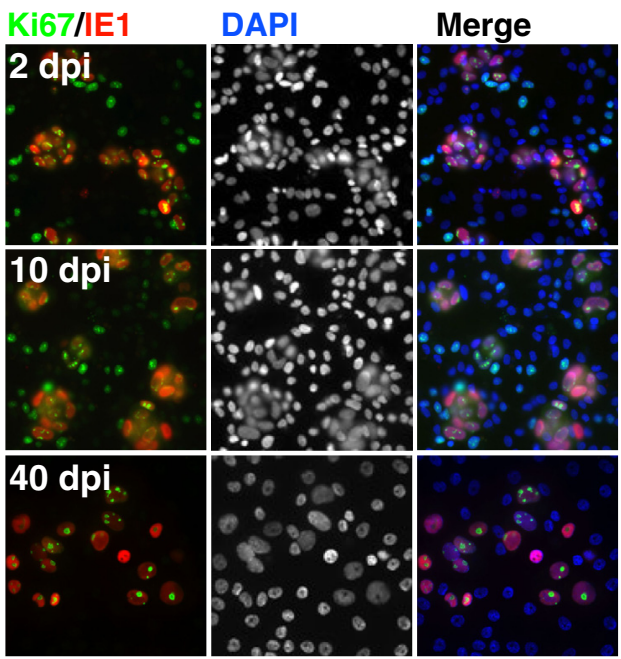


placentas expressed representative proteins from all kinetic classes: immediate early IE1 and IE2, early gB, and late pp28 (Figure 2B). IE2 expression was considerably lower than IE1 expression in AmEpCs at 3 days after infection. Moreover, expression of $\mathrm{gB}$ and $\mathrm{pp} 28$ was delayed in late gestation AmEpCs. All of the viral proteins were detected equally in ARPE-19 cells at 3 and 9 days after infection.

Primary AmEpCs from mid-gestation (17 to 22.5 weeks, $n=8$ ) and late gestation (29 to 39.3 weeks, $n=3$ ) placentas from various donors were infected with VR1814, and the cells expressing IE1 were counted at 2 and 10 days. Although levels of infection varied among donors, 50\% to 90\% of mid-gestation AmEpCs expressed IE1 protein (Figure 2C), and only 5\% to $20 \%$ of late gestation AmEpCs were infected (Figure 2C). Interestingly, the number of infected cells did not increase from 2 to 10 days after infection (Figure 2C) nor did the sizes of infected foci (Figure 2D). Similarly, virus progeny released from AmEpCs slightly increased at early time points after infection (6 and 15 days after infection) and plateaued at late time points (37 and 52 days after infection). IE1 and Ki-67 were co-expressed in small foci of infected AmEpCs as late as 40 days after infection (Figure 2E), suggesting that HCMVinfected cells continued to survive and proliferate for weeks and released low levels of progeny $\left(8.6 \times 10^{3}\right.$ plaqueforming units $/ \mathrm{mL}$ at 52 days after infection) (Figure 2D).

Notably, many of the infected AmEpCs failed to form a compact perinuclear viral assembly compartment (VAC) (Figure 3, A-C), a site of virion maturation ${ }^{53-55}$ typically formed in infected ARPE-19 cells (Figure 3, A-C). In infected AmEpCs, pp65, the most abundant virion tegument protein, remained in the nuclei at late time points (Figure 3B). The VAC incorporates endosomal markers corresponding to multivesicular bodies (MVBs) and is a key site for virus assembly and egress, ${ }^{53,54}$ and maturation defects occur when biogenesis is disrupted. ${ }^{56}$ In infected AmEpCs, CD63, a marker of MVBs, accumulated in vesicles with $\mathrm{gB}$, identifying these smaller vesicles as MVBs (Figure 3, C and D), and in the VAC of infected ARPE-19 cells (Figure 3C). MVBs formed in AmEpCs infected in vitro (Figure $3 \mathrm{D}$ ) had a morphology similar to those in amniotic membranes infected in utero (Figure 1, G-I, K, $\mathrm{M}$, and $\mathrm{N}$ ).

Quantification of progeny virus in human foreskin fibroblasts showed that moderate titers were released from mid-gestation AmEpCs and 10-fold lower titers from late gestation cells (Figure 3E). Progeny retained tropism for epithelial cells, although infection failed to spread efficiently in AmEpCs, and titers were lower than in human foreskin fibroblasts (Figure 3F). Together, the results suggest that HCMV persistently infects AmEpCs.

To determine whether the virion entry requirements for HCMV infection of ARPE-19 cells pertained to primary AmEpCs, we tested whether virion entry depends on a functional pentamer complex $\mathrm{gH} / \mathrm{gL} / \mathrm{pUL} 128$ pUL131A. ${ }^{40,50,57-59}$ Neutralization of VR1814 infection by human MAbs to UL130/131A (TRL310) and $\mathrm{gB}$ (TRL345) was assayed and compared with neutralization by hyperimmune globulin and a negative control MAb (Figure 3G). The MAb to UL130/131A had a 100-fold higher neutralizing titer than the $\mathrm{gB}$-specific $\mathrm{MAb}$ and 1000-fold greater activity than hyperimmune globulin, whereas the negative control MAb lacked neutralizing activity. The results confirmed that the pentamer complex and gB both contribute to AmEpC infection.

\section{HCMV-Infected AmEpCs Induce IFN- $\beta$ Expression}

The finding that AmEpCs formed small foci of infection suggested that virus spread might be limited by an IFN response. IRF7 is one of the major players in virus-induced IFN production that is central to innate immunity. ${ }^{60}$ Interestingly, IRF3 is rapidly degraded in virus-infected cells, ${ }^{61}$ whereas IRF7 expression is critical for the late induction phase and not the early phase. ${ }^{62}$ HCMV infection triggers a strong innate immune response that includes transcription of the IFN- $\beta$ gene via activation of IRF3 without viral gene expression, ${ }^{63}$ blocked by the newly synthesized IE2. ${ }^{64}$ Next, we examined nuclear translocation and phosphorylation of IRF3 and IRF7. Immunostaining showed weak IRF7 accumulation in the nuclei of VR1814-infected AmEpCs at 4 days after infection and a strong nuclear pattern at 12 days (Figure 4A). Likewise, TB40E-infected AmEpCs showed nuclear staining at 12 days, in contrast to mutant TB40E $\Delta 131 \mathrm{~A}$ that fails to infect ARPE-19 cells, ${ }^{65}$ suggesting virion entry was required (Figure 4A). Immunoblot analysis confirmed that the activated form phospho-IRF7 was present at 3 days after infection and increased by 12 days (Figure 4B), but

\footnotetext{
Figure 2 A: Isolated amniotic epithelial cells (AmEpCs) were mock infected (control) or infected with VR1814 and fixed at 7 days postinfection (dpi). Immunostaining of stem cell markers (green) and viral proteins (red) in control (top panels) and infected cells (bottom panels). Nuclei were stained with DAPI (blue). Colocalization of green and blue signals (turquoise) and red and green signals (yellow). B: Immunoblotting of viral proteins. Lysates from midgestation (17 weeks) and late gestation (39 weeks) AmEpCs and ARPE-19 cells at indicated time points were immunoblotted with monoclonal antibodies to viral proteins and actin (loading control). CH160 was used to detect immediate early (IE) 1 and IE2. C: Numbers of IE1-positive cells stained with CH443 (IE1) and counterstained with DAPI were calculated at 2 and $10 \mathrm{dpi}$. At least 10 images (magnification $\times 200$ ) from randomly selected areas were photographed using a Nikon Eclipse 50i microscope equipped with a SPOT 7.4 Slider camera controlled by SPOT 2.0 Advanced software (Diagnostic Instruments, Sterling, MI). Graph shows IE-positive cell numbers. D: Phase microscopy of HCMV-infected AmEpCs at the indicated times after infection. Numbers indicate titers of progeny virions in human foreskin fibroblasts. Foci of infected cells indicated by green dotted lines. E: Immunostaining for Ki-67 (green) and IE1 (CH443) (red) in uninfected control and VR1814-infected AmEpCs. Nuclei were stained with DAPI. Data are given as means \pm SEM (C). Scale bars: $50 \mu \mathrm{m}$ (A and E); $100 \mu \mathrm{m}$ (D). Original magnifications: $\times 200(\mathbf{A}$ and $\mathbf{E}) ; \times 100$ (D). PFU, plaque-forming unit.
} 
A

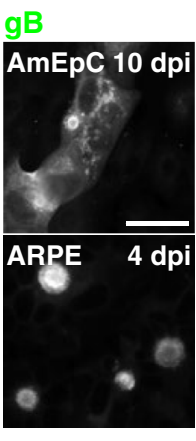

C

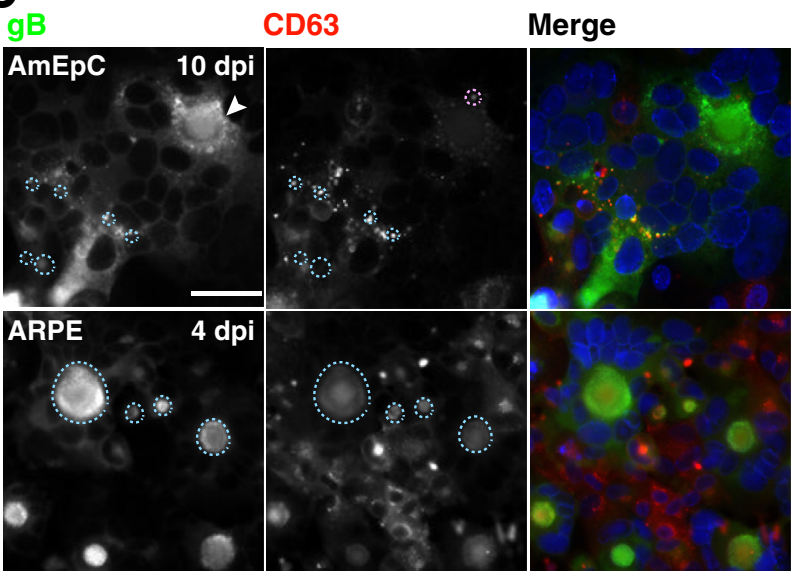

B
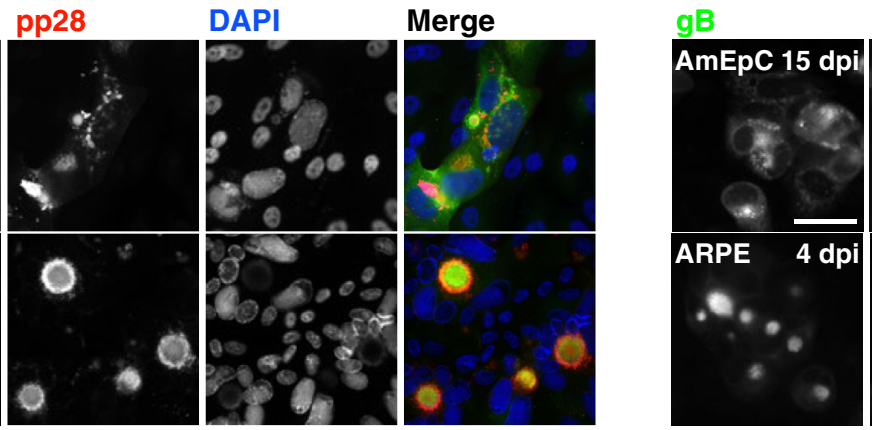

pp65
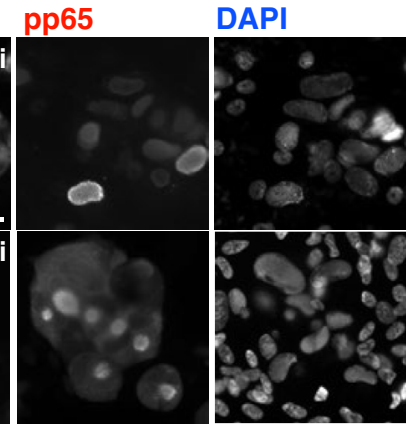

Merge

D

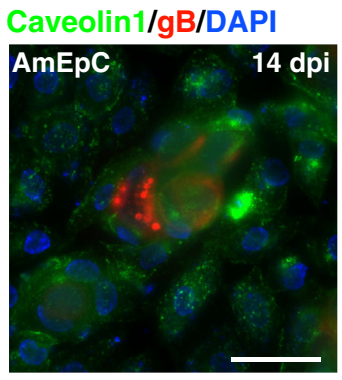

E Titered on HFF
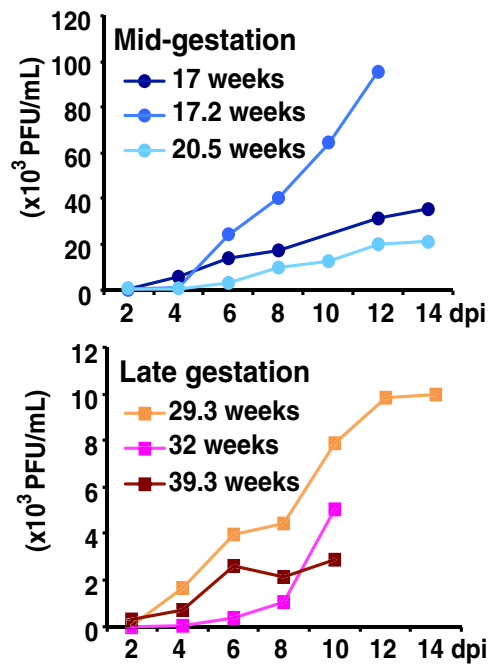

F Titered on AmEpC

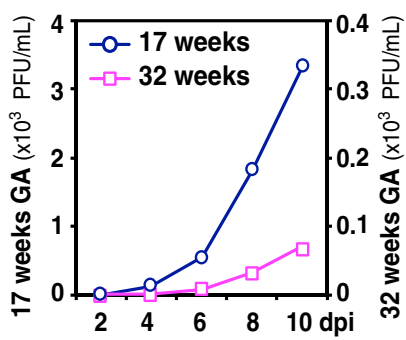

G

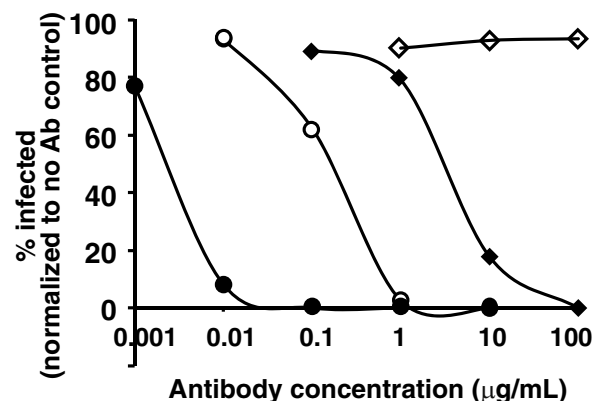

Antibody concentration $(\mu \mathrm{g} / \mathrm{mL})$

- $\alpha$-pentamer $\diamond$ HIG

$0 \alpha-g B$

$\diamond$ Control Ab

Figure 3 A-C: Immunostaining of human cytomegalovirus (HCMV) gB (green) and pp28 (red) (A), gB (green) and pp65 (red) (B), and gB (green) and CD63 (red) (C) in VR1814-infected amniotic epithelial cells (AmEpCs) and ARPE-19 cells at indicated time points. Blue dotted lines delineate sites of colocalization. Arrowhead and pink circle also indicate colocalization. D: Immunostaining of caveolin 1 (green) and $\mathrm{gB}$ (red) in VR1814-infected AmEpCs. E: Infected AmEpCs from early and late gestation released progeny virions. Conditioned media from VR1814infected AmEpCs from different gestational ages were collected every other day and titered in human foreskin fibroblasts (HFFs). F: Progeny virions from both early gestation (17 weeks, left $y$ axis) and late gestation (32 weeks, right $y$ axis) AmEpCs retained tropism for epithelial cells, as indicated by titration on AmEpCs (23.5 weeks' gestation). G: VR1814 inoculum was pre-incubated with medium alone or serial dilutions of anti-gB monoclonal antibody (Mab; TRL345), anti-pentamer MAb (TRL310, 1F11), hyperimmune globulin (HIG; Cytotect), or negative control antibody (Synagis) and then added to AmEpCs (22.5 weeks' gestation). Percentages of infected cells were determined by counting immediate early 1 (CH443)positive cells and normalized to counts from the no antibody control. Data points represent means of two independent experiments each with three replicates (G). Scale bar $=50 \mu \mathrm{m}(\mathbf{A}-\mathbf{D})$. Original magnification, $\times 200(\mathbf{A}-\mathbf{D})$. dpi, days postinfection; GA, gestational age; PFU, plaque-forming unit. 


\section{A}

IRF7/IE1/DAP
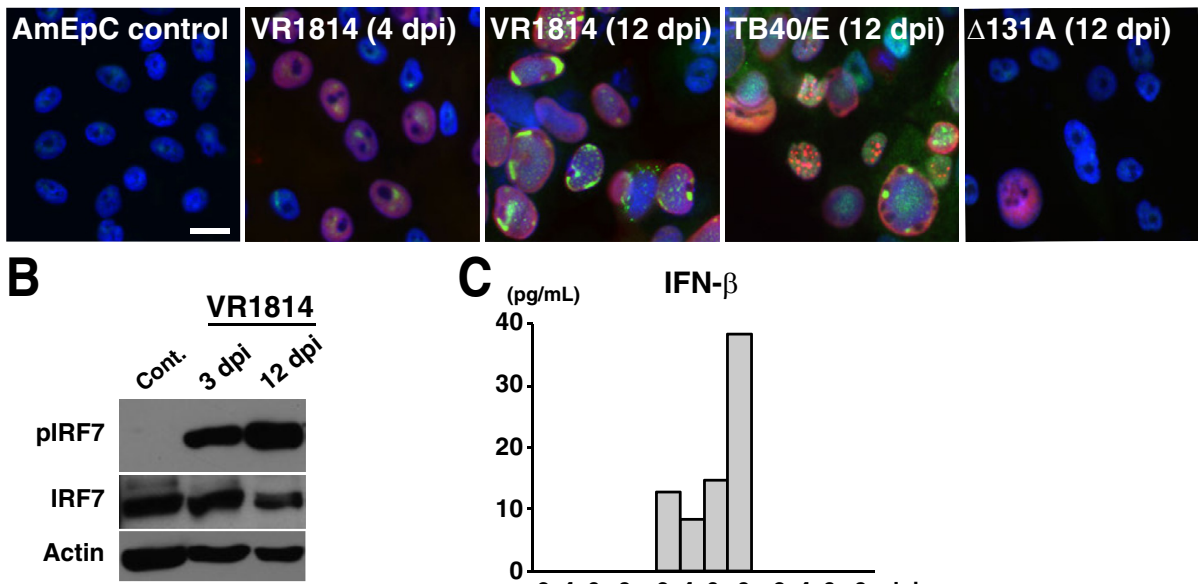

C
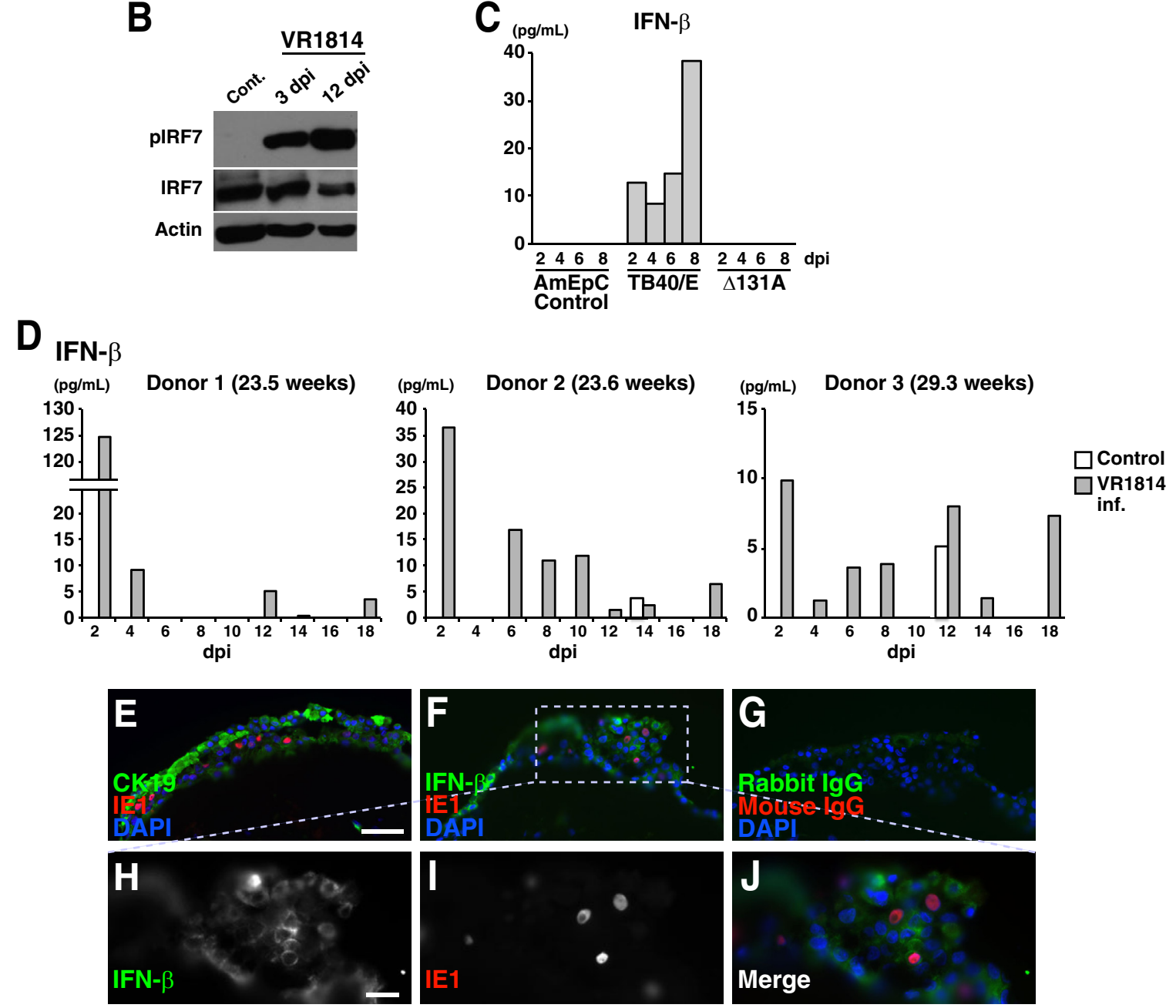

Figure 4 A: Immunostaining of interferon regulatory factor (IRF) 7 in mock-infected control (Cont.) and VR1814, TB40/E or $\Delta 131 \mathrm{~A}$ mutant virus-infected cells at indicated time points. Nuclei were stained with DAPI. B: Human cytomegalovirus (HCMV)-infected cells activate IRF7. Cell lysates from mock-infected control and VR1814-infected (inf.) amniotic epithelial cells (AmEpCs) at indicated time points were immunoblotted with antibodies to phospho-IRF7 (pIRF7), IRF7, and actin (loading control). Results are representative of at least four independent experiments. C: Levels of interferon (IFN)- $\beta$ in conditioned media from mock-infected control and TB40/E or $\triangle 131 \mathrm{~A}$-infected AmEpCs were quantified by enzyme-linked immunosorbent assay (ELISA). D: Levels of IFN- $\beta$ in conditioned media from mock-infected control and VR1814-infected (inf.) AmEpCs from three donors were quantified by ELISA. E-J: Up-regulation of IFN- $\beta$ in an explant of amniochorionic membrane (19.3 weeks' gestation) infected ex vivo with VR1814. Immunostaining of CK19 (green; E), IFN- $\beta$ (green; F), and immediate early (IE) 1 (red; $\mathbf{E}$ and $\mathbf{F}$ ) at 5 days postinfection (dpi). The dashed box in $\mathbf{F}$ indicates the area shown at high magnification in $\mathbf{H}-\mathbf{J}$. G: No specific staining was observed using isotype control antibodies. Scale bar $=20 \mu \mathrm{m}(\mathbf{A}$ and $\mathbf{H}-\mathbf{J}) ; 50 \mu \mathrm{m}(\mathbf{E}-\mathbf{G})$. Original magnifications: $\times 200(\mathbf{A}$ and $\mathbf{E}-\mathbf{G}) ; \times 400(\mathbf{H}-\mathbf{J})$.

IRF3 was not activated during the same period (data not shown).

Consistent with IRF7 activation, virion penetration, and downstream induction of interferon response genes, TB40Einfected AmEpCs produced IFN- $\beta$, but cells infected with TB40/E $\Delta 131 \mathrm{~A}$, which fails to enter epithelial cells, did not (Figure 4C). In addition, IFN- $\alpha$ was not detected in infected AmEpCs (data not shown). ELISA values for IFN- $\beta$ in conditioned media from VR1814-infected AmEpCs from mid-gestation placentas are shown $(n=3)$ (Figure 4D). After a robust induction at 2 days after infection, IFN- $\beta$ levels decreased and low levels were detected at later time points monitored $(<10 \mathrm{pg} / \mathrm{mL})$. Infected AmEpCs from mid-gestation (23.5 and 23.6 weeks) made higher levels of IFN- $\beta$ than those from late gestation (29.3 weeks), and the levels varied by donor. 
A

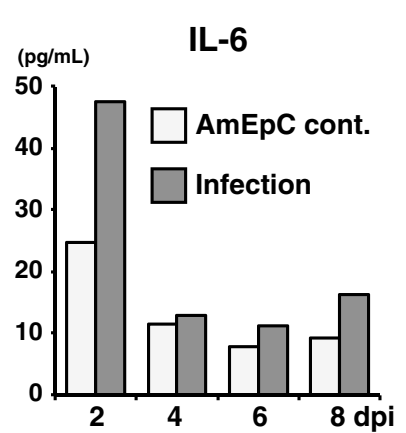

B

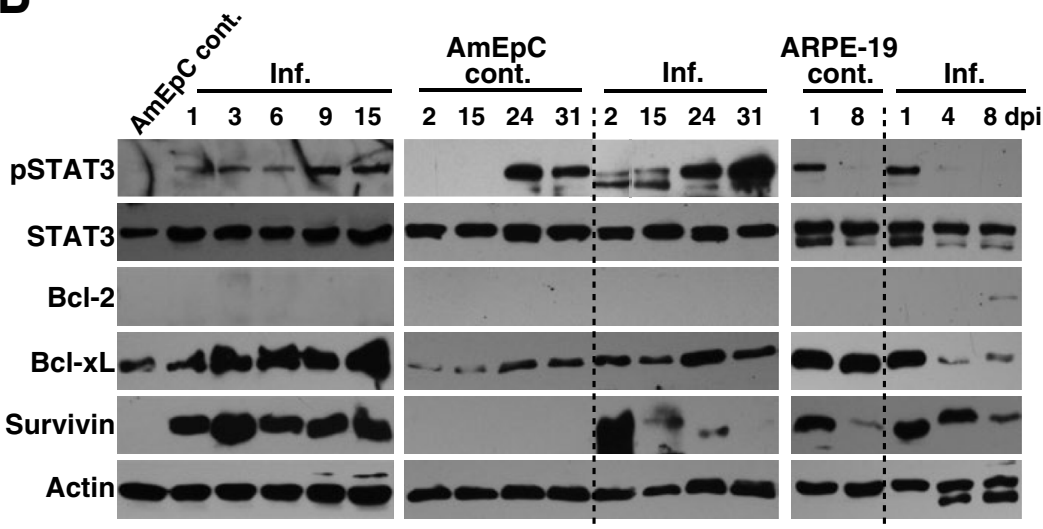

C

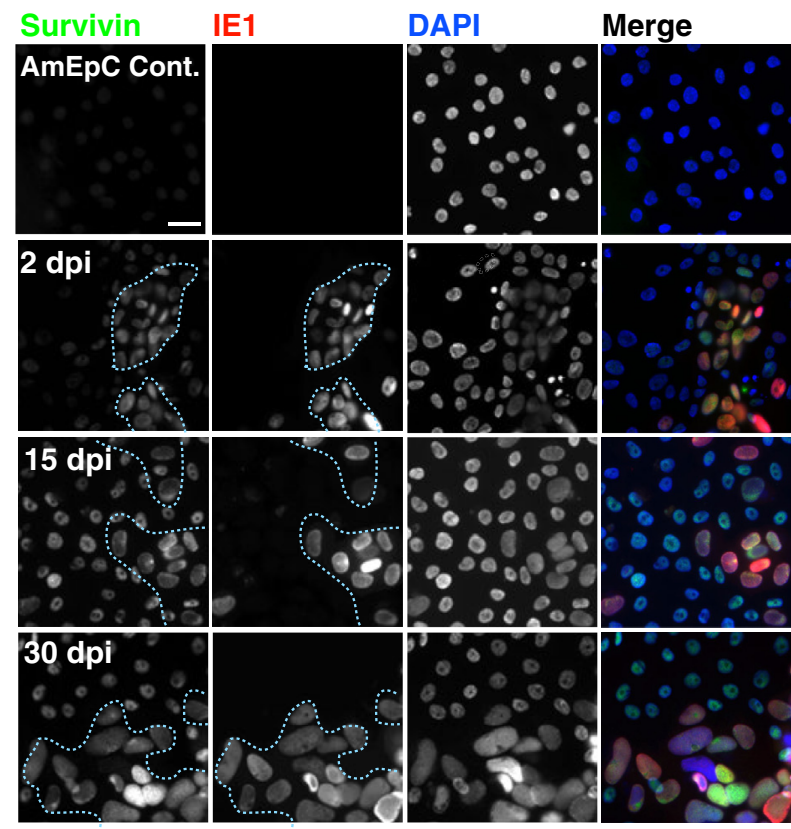

E

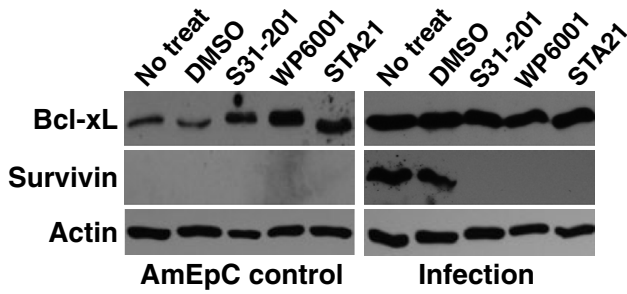

D

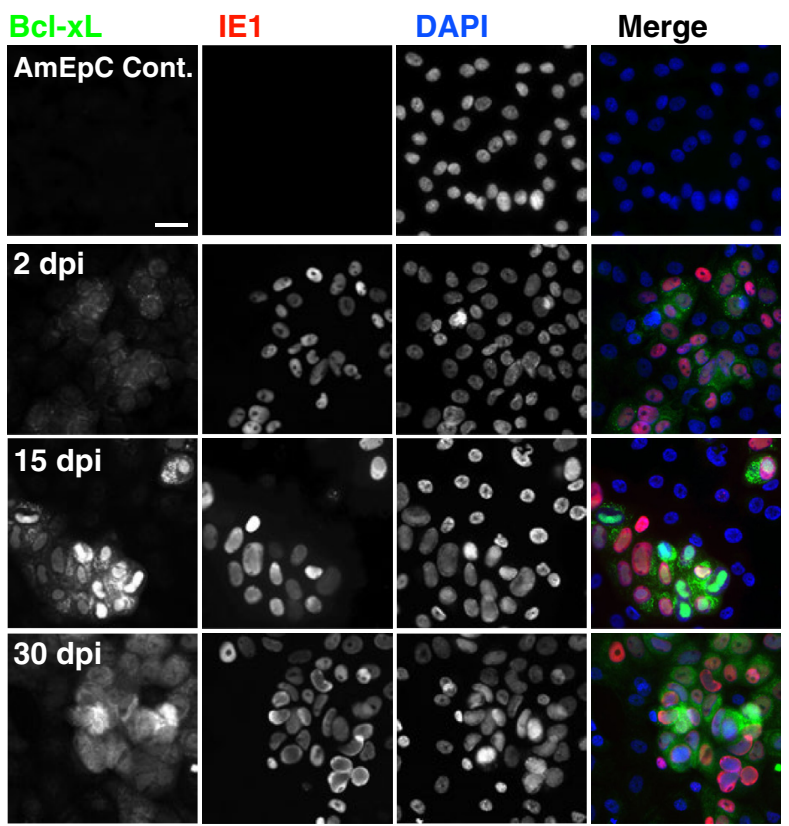

$\mathbf{F}$

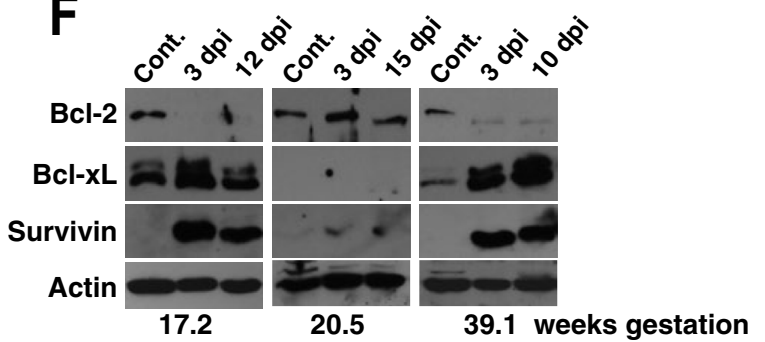

Figure 5 A: IL-6 levels in conditioned media from mock-infected control (cont.) and VR1814-infected amniotic epithelial cells (AmEpCs) quantified by enzyme-linked immunosorbent assay. Similar results were obtained with four cell preparations. B: Human cytomegalovirus (HCMV) infection activates STAT3 and up-regulates anti-apoptotic proteins. Cell lysates from mock-infected control and VR1814-infected AmEpCs or ARPE-19 cells at indicated times were immunoblotted with antibodies to phospho-STAT3 (pSTAT3), STAT3, Bcl-2, Bcl- $\mathrm{x}_{\mathrm{L}}$, survivin, and actin (loading control). Results are representative of at least three independent experiments. C and D: Immunostaining of survivin (B), Bcl- $x_{L}$ (C), and immediate early (IE) 1 (CH443) in mock-infected control and VR1814-infected cells. Nuclei were stained with DAPI. Blue dashes delineate foci of infection. E: Effects of STAT3 inhibitors on Bcl- $x_{L}$ and survivin expression. Mock-infected control and VR1814-infected AmEpCs were cultured with medium alone (no treat), STAT3 inhibitors S31-201 (100 $\mu \mathrm{mol} / \mathrm{L})$, WP6001 (5 $\mu \mathrm{mol} / \mathrm{L})$, or STA21 $(50 \mu \mathrm{mol} / \mathrm{L})$, or the vehicle dimethyl sulfoxide (DMSO). Cell lysates at 3 days postinfection (dpi) were immunoblotted with antibodies to Bcl- $\mathrm{X}_{\mathrm{L}}$ survivin, and actin (loading control). Results are representative of at least four independent experiments. F: Cell lysates from mock-infected control and VR1814-infected AmEpCs from different gestational ages were immunoblotted with antibodies to Bcl-2, Bcl- $\mathrm{X}_{\mathrm{L}}$, survivin, and actin (loading control). Scale bar $=50 \mu \mathrm{m}(\mathbf{C}$ and $\mathbf{D})$. Original magnification, $\times 200(\mathbf{C}$ and $\mathbf{D})$. 


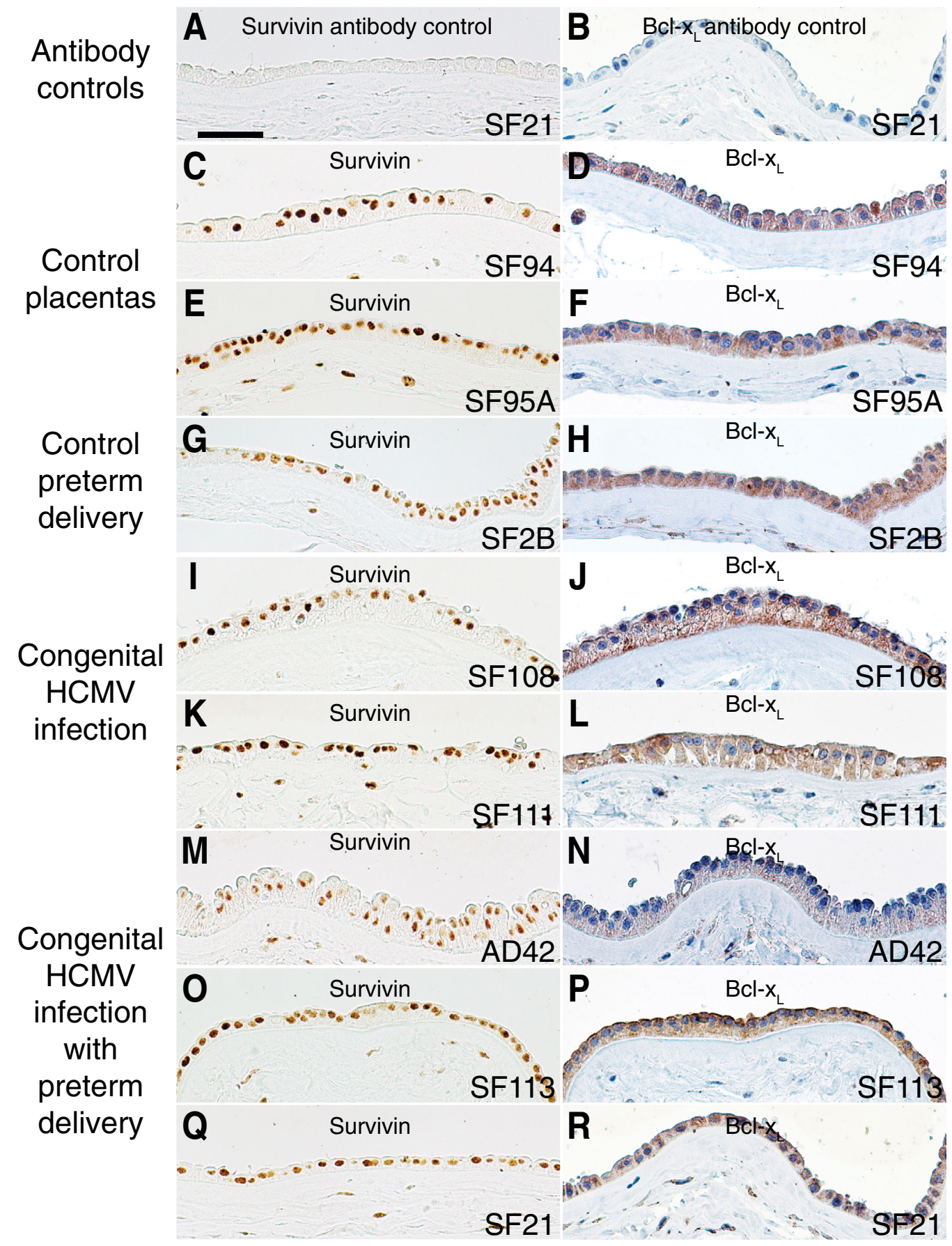

Figure 6 Representative immunohistochemical staining for survivin and $\mathrm{Bcl}-\mathrm{x}_{\mathrm{L}}$ in amniotic membranes of placentas from uninfected control, preterm delivery, congenital human cytomegalovirus (HCMV) infection, and congenital infection with preterm delivery. Thirty-four membranes (13 expressing HCMV proteins) were examined for survivin expression, and 17 membranes (8 expressing HCMV proteins) were examined for Bcl- $\mathrm{X}_{\mathrm{L}}$ expression. Sample designations and sources are described in Materials and Methods. A: Section of SF21 adjacent to the section in $\mathbf{Q}$ stained with isotype control for rabbit monoclonal antibody to anti-survivin. B: Section of SF21 adjacent to the section in $\mathbf{R}$ stained with control antisera for rabbit polyclonal anti-Bcl- $x_{\mathrm{L}}$ antibody. Survivin and Bcl- $\mathrm{X}_{\mathrm{L}}$ immunostaining of amniotic membranes: control (uninfected; $\mathbf{C}-\mathbf{F}$ ); control with preterm delivery ( $\mathbf{G}$ and $\mathbf{H})$; congenital HCMV infection (I-L); and congenital HCMV infection with preterm delivery (M-R).

To assess whether IFN- $\beta$ was made in intact tissues, explants of amniochorionic membranes from mid-gestation placentas were plated on Matrigel, with chorionic membrane facing downward and the amniotic epithelium surface facing upward (ie, toward the fetus in utero). After attachment, the explants were infected with VR1814. Representative immunostaining showed that CK19-positive infected AmEpCs expressed IE1 (Figure 4E). Infected foci formed at 7 days, indicating viral replication, but the spread of infection was restricted in the tissue environment 
(Figure $4, \mathrm{~F}-\mathrm{J}$ ). In addition, IFN- $\beta$ robustly increased in uninfected AmEpCs, but expression was reduced in IE1positive infected cells (Figure 4, F and $\mathrm{H}-\mathrm{J}$ ). Together, the results suggested that HCMV infection elicits an innate immune response in the epithelium of amniotic membranes and that induction of IFN- $\beta$ limits virus spread to neighboring cells in the tissue environment of intact amniotic membranes.

\section{Infected AmEpCs Activate STAT3-Dependent and STAT3-Independent Survival Pathways}

IL-6 stimulation induces rapid phosphorylation of STAT3 (pSTAT3), which controls several apoptotic pathway genes, including Bcl family members, such as Bcl-2 and Bcl- $\mathrm{x}_{\mathrm{L}}$, and the inhibitors of apoptosis family genes, such as survivin. To determine whether HCMV infection activates IL6-STAT3 signaling in proliferating, persistently infected AmEpCs, IL-6 production was measured and found to increase at day 2 compared to uninfected cells (Figure 5A). In contrast, the effect on tumor necrosis factor- $\alpha$ varied depending on the donor and was inconsistent (data not shown).

Next, we determined whether HCMV-infected AmEpCs activate STAT3 signaling. For these experiments, pSTAT3 levels were assessed by immunoblotting and compared with levels in ARPE-19 cells. In kinetic studies, pSTAT3 was detected at 1 day and increased by 15 days after infection (Figure 5B). Both survivin and Bcl- $\mathrm{x}_{\mathrm{L}}$ were strongly up-regulated, whereas Bcl-2 was lower than the detection limit at all time points (Figure 5B). During longer intervals, pSTAT3, survivin, and $\mathrm{Bcl}-\mathrm{x}_{\mathrm{L}}$ were detected as late as 24 days after infection (Figure 5B). In contrast, pSTAT3, survivin, and Bcl- $\mathrm{x}_{\mathrm{L}}$ were briefly detected in ARPE-19 cells at 1 day after infection, but not later (Figure 5B). When infected AmEpCs were immunostained for survivin and $\mathrm{Bcl}-\mathrm{x}_{\mathrm{L}}$, we observed that survivin was induced at 2 days after infection, expressed at 15 and 30 days, and weakly expressed in bystander cells (Figure 5C). Likewise, Bcl$\mathrm{x}_{\mathrm{L}}$ was induced at 2 days and expressed throughout the 30-day observation period, mainly in infected AmEpCs (Figure 5D). Trace amounts of survivin and $\mathrm{Bcl}-\mathrm{x}_{\mathrm{L}}$ were seen in infected ARPE-19 cells at 2 days after infection but not at later time points (data not shown).

To further examine the dependence of HCMV-infected AmEpCs on pSTAT3 for survival, STAT3 activity was blocked with inhibitors. These drugs included S31-201, an inhibitor of phosphorylation and dimerization, ${ }^{66}$ WP1066, an inhibitor of JAK2 tyrosine kinase, ${ }^{67}$ and STA21, an inhibitor of STAT3 dimerization and DNA binding. ${ }^{68}$ Treatment with STAT3 inhibitors blocked survivin induction in infected AmEpCs, but not in vehicle dimethyl sulfoxide-treated cells (Figure 5E). There was no effect of STAT3 inhibitors on survivin expression in control cells. In contrast, Bcl- $\mathrm{x}_{\mathrm{L}}$ induction in infected cells was not blocked by STAT3 inhibitors (Figure 5E), indicating that $\mathrm{Bcl}-\mathrm{x}_{\mathrm{L}}$ upregulation is not STAT3 dependent. Together, the results showed that HCMV-infected AmEpCs up-regulate the antiapoptotic proteins survivin and $\mathrm{Bcl}-\mathrm{x}_{\mathrm{L}}$ in vitro through STAT3-dependent and STAT3-independent pathways, respectively, promoting cell proliferation and prolonged survival.

Further analysis of infected AmEpCs from mid-gestation (17.2 and 20.5 weeks) and late gestation (39.1 weeks) confirmed that expression of the anti-apoptotic proteins varied by donor. Figure $5 \mathrm{~F}$ shows three examples of eight cell preparations (including two in Figure 5B). Expression levels of $\mathrm{Bcl}-\mathrm{x}_{\mathrm{L}}$ varied in different cell preparations. Interestingly, when Bcl- $\mathrm{x}_{\mathrm{L}}$ was expressed at low levels (20.5 weeks' gestation), AmEpCs had low infectivity (Figure 2B). However, AmEpCs from this donor expressed $\mathrm{Bcl}-2$ and trace amounts of survivin. Bcl-2 was expressed in AmEpCs from two other donors but was lower than detection levels after infection. Together, these results indicate that expression of anti-apoptotic proteins could modulate persistent HCMV infection and that expression varies by donor and gestational age.

\section{Survivin and $\mathrm{BCl}-\mathrm{x}_{\mathrm{L}}$ Expressed in Amniotic Membranes of Congenitally Infected Placentas}

Having found that primary AmEpCs isolated from placentas infected with VR1814 in vitro up-regulate survivin and $\mathrm{Bcl}-\mathrm{x}_{\mathrm{L}}$, sections of amniotic membranes from placentas (Figure 1 and Table 1) were immunostained to determine whether the cell survival proteins were upregulated in the tissue environment in utero. Amniotic membranes from control placentas, preterm deliveries, and congenital infection, with and without preterm delivery, were immunostained for survivin and $\mathrm{Bcl}-\mathrm{x}_{\mathrm{L}}$. Representative sections from staining of 34 membranes for survivin and 17 membranes for $\mathrm{Bcl}-\mathrm{x}_{\mathrm{L}}$ are shown (Figure 6). Like AmEpCs infected in vitro, survivin stained in a nuclear pattern (Figure 6, I, K, M, O, and Q) and $\mathrm{Bcl}-\mathrm{x}_{\mathrm{L}}$ stained in a punctate cytoplasmic pattern (Figure 6, J, L, N, P, and R) in amniotic membranes infected in utero. Unexpectedly, parallel analysis of control amniotic membranes revealed that survivin (Figure 6, C, E, and G) and Bcl- $\mathrm{x}_{\mathrm{L}}$ (Figure 6, D, F, and $\mathrm{H}$ ) were both expressed in the amniotic epithelium. In contrast, control antibodies, polyclonal rabbit antisera, and isotype control rabbit $\mathrm{MAb}$ failed to immunostain amniotic membranes (Figure 6, A and B). Additional analysis of amniotic membranes from cases of IUGR with underlying congenital HCMV infection, previously reported, ${ }^{6}$ further confirmed that amniotic membranes containing viral proteins also express the anti-apoptotic proteins survivin and $B c l-x_{L}$ (data not shown). Together, the results suggest that congenital HCMV infection and virus transmission could result in infection of the amniotic epithelium and that the intrinsic longevity 
of these progenitor/stem cells could contribute to a state of persistent infection.

\section{Discussion}

We previously reported that HCMV proteins are present in amniotic membranes of placentas from pregnancies complicated by IUGR with underlying congenital infection. ${ }^{6}$ Herein, we examined a repository of placentas from diagnosed congenital HCMV infection, IUGR, and preterm delivery to determine whether detection of viral proteins in amniotic membranes was associated with transmission and studied the course of infection in primary AmEpCs isolated from placentas from different donors and gestational ages. Analysis of amniotic membranes from 33 placentas showed that HCMV replicates in amniotic membranes of placentas from symptomatic and asymptomatic congenital infection and preterm deliveries confirmed by detection of viral DNA in amniotic fluid at mid-gestation and/or saliva specimens from newborns. Studies of primary AmEpCs isolated from 16 mid-gestation and late gestation placentas show that pathogenic HCMV strains replicate in AmEpCs and down-regulate proteins that maintain progenitor cell properties. Infected AmEpCs proliferated and formed small foci of infection that failed to spread and survived for months with long-term maintenance of viral genomes (data not shown). Low levels of progeny virions that retained epithelial cell tropism were continuously released. In explants of amniotic membranes infected ex vivo, IFN- $\beta$ was produced and could limit virus spread in the tissue environment. In infected AmEpCs, the anti-apoptotic proteins survivin and $\mathrm{Bcl}-\mathrm{x}_{\mathrm{L}}$ were up-regulated by STAT3-dependent and STAT3-independent mechanisms, respectively. AmEpCs in membranes of placentas with congenital HCMV infection expressed survivin and $\mathrm{Bcl}-\mathrm{x}_{\mathrm{L}}$. Detection of these proteins in amniotic membranes from control placentas suggested an opportune environment for viral persistence. Our discovery that HCMV establishes persistent infection in the amniotic epithelium could explain why high levels of viral DNA in amniotic fluid do not predict poor outcome but could reflect the capacity for persistent infection in amniotic membranes dependent on individual variation and gestational age. In this context, we have also documented that AmEpCs are highly permissive to infection by prototype Zika virus and recently isolated Nicaraguan strains of Zika virus (2016) associated with microcephaly, ${ }^{28}$ suggesting that, like HCMV, infection of AmEpCs could play a major role in viral pathogenesis, leading to fetal abnormalities and preterm birth. In this regard, AmEpCs isolated from mid-gestation placentas produced higher titers of infectious virus progeny than cells from late gestation. In contrast to HCMV, however, Zika produced lytic infection of these cells.

The course of HCMV infection in primary cells could depend on the tissue of origin, stem cell properties, and innate immune responses associated with persistent and lytic infection in endothelial cells. ${ }^{21,22,44,69}$ Herein, we found marked differences in epithelial cells by comparing VR1814 infection of primary AmEpCs and ARPE-19 cells, highly passaged differentiated cells ${ }^{70}$ used as a model for lytic infection. ${ }^{46-52,71}$ Immediately evident was mislocalization of pp65, gB, and pp28, impaired transport of these proteins to MVBs, and failure to form a compact VAC that could reduce virus titers in infected AmEpCs. An innate immune response and prolonged IFN production that suppresses infection is usually transient because of expression of HCMV proteins that interfere with the response, which include pp65 delivery to the nucleus by incoming virions ${ }^{72}$ and IE2 that functions as an IFN- $\beta$ antagonist. ${ }^{64} \mathrm{We}$ observed that newly synthesized pp65 was retained in the nucleus and that IE2 expression was delayed, suggesting viral suppression of the innate immune response could be partially impaired. Cellular miRNA could also participate in events that lead to persistent infection, especially the miR200 family, enriched in epithelial tissues, that modifies host innate immune responses to microbial pathogens. ${ }^{73}$ Overexpression of the miR-200 cluster decreases HCMV titers in fibroblasts, ${ }^{74}$ and miR-200 levels were high in latently infected $\mathrm{CD} 34^{+}$cells and in persistently infected monocytes, but not in lytically infected macrophages. ${ }^{75}$ In addition, miR-200 family members target HCMV UL122 $3^{\prime}$ untranslated region, inhibiting IE2 translation, ${ }^{75}$ and target Sec23a, which is involved in endoplasmic reticulum-toGolgi vesicle transport and could modulate VAC formation. $^{76}$ Interestingly, miR-200 was expressed in HCMVinfected AmEpCs and increased late in persistent infection (T.T., unpublished observation). Future studies will elucidate the contributions of miR-200 family to persistent infection in AmEpCs.

Apoptosis is a host defense mechanism to dispose of damaged cells; however, the herpesvirus family has the ability to deregulate apoptotic pathways to complete their life cycles. Activated STAT3 prolongs the survival of cells infected with varicella zoster virus in skin xenografts ${ }^{77}$ and promotes malignant transformation and proliferation of cells by Epstein-Barr ${ }^{78-80}$ and Kaposi sarcoma virus. ${ }^{81}$ HCMVinfected endothelial cells up-regulate survivin via IL-6, a cytokine in the viral secretome, ${ }^{82}$ and infected primary hepatocytes, limited in viral replication, activate IL6-JAK-STAT3 signaling pathways that favor cell proliferation and up-regulate survivin. ${ }^{83} \mathrm{We}$ found that HCMV-infected AmEpCs rapidly and persistently activate STAT3 at Y705, inducing expression of anti-apoptotic survivin and Bcl- $\mathrm{x}_{\mathrm{L}}$ by STAT3-dependent and STAT3independent pathways, respectively. Both $\mathrm{Bcl}-\mathrm{x}_{\mathrm{L}}$ and vMIA interact with GADD45 $\alpha$, enhancing cell death suppression, and GADD45 family members promote $\mathrm{Bcl}-\mathrm{x}_{\mathrm{L}}$ and vMIA expression. ${ }^{84}$ Moreover, HCMV infection activates NF- $\mathrm{BB}$ signaling in fibroblasts and monocytes, ${ }^{85-88}$ and NF- $\kappa B$ regulates GADD $45 \alpha$ and Bcl- $\mathrm{x}_{\mathrm{L}}$. Both NF- $\kappa \mathrm{B}$ and IE proteins stimulate IL-6 production, ${ }^{83,89,90}$ and an IL-6-related pathway up-regulates GADD $45 \beta$ in herpes simplex virus-1-infected corneal epithelial cells. ${ }^{91}$ HCMV 
infection likely activates NF- $\mathrm{BB}$ and IL-6 that could upregulate GADD45 $\alpha$ and amplify $\mathrm{Bcl}-\mathrm{x}_{\mathrm{L}}$ expression in AmEpCs. In contrast, ARPE-19 cells failed to activate STAT3 or up-regulate the anti-apoptotic proteins survivin and $\mathrm{Bcl}-\mathrm{x}_{\mathrm{L}}$, except at 1 day after infection. It was reported that HCMV-infected fibroblasts rapidly accumulate unphosphorylated STAT3 in the nucleus and disrupt IL-6-induced STAT3 activation, events regulated by IE1 protein that diminish viral DNA synthesis and gene expression. ${ }^{92}$ In contrast, results of our studies showed that AmEpCs maintain STAT3 activation, which is linked to persistent infection and cell survival.

In conclusion, our studies of placentas from congenital infection and primary cells isolated from various donors and placentas from mid-gestation and late gestation suggest that persistent HCMV infection in fetal membranes could promote inflammation ${ }^{20,21}$ and contribute to preterm labor and delivery. ${ }^{27}$ Understanding the basis for persistent infection in AmEpCs could lead to therapeutic strategies to prevent congenital disease and pregnancy complications by targeting viral functions that promote persistence and enhancing host antiviral responses that suppress infection.

\section{Acknowledgments}

We thank Dr. Mitsuru Tsuge for early studies on VR1814 infection of amniotic epithelial cells, members of Susan Fisher's laboratory for thoughtful discussions, Dr. Barbara Adler for providing TB40/E viruses, Dr. Larry Kauvar for human monoclonal antibodies, Stephanie Leong for consenting patients to donate samples, and Mirhan Kapidzic for excellent technical assistance.

\section{References}

1. Pass RF, Stagno S, Myers GJ, Alford CA: Outcome of symptomatic congenital cytomegalovirus infection: results of long-term longitudinal follow-up. Pediatrics 1980, 66:758-762

2. Demmler GJ: Congenital cytomegalovirus infection and disease. Adv Pediatr Infect Dis 1996, 11:135-162

3. Cannon MJ, Schmid DS, Hyde TB: Review of cytomegalovirus seroprevalence and demographic characteristics associated with infection. Rev Med Virol 2010, 20:202-213

4. Colugnati FA, Staras SA, Dollard SC, Cannon MJ: Incidence of cytomegalovirus infection among the general population and pregnant women in the United States. BMC Infect Dis 2007, 7:71

5. Maidji E, Nigro G, Tabata T, McDonagh S, Nozawa N, Shiboski S, Muci S, Anceschi MM, Aziz N, Adler SP, Pereira L: Antibody treatment promotes compensation for human cytomegalovirusinduced pathogenesis and a hypoxia-like condition in placentas with congenital infection. Am J Pathol 2010, 177:1298-1310

6. Pereira L, Petitt M, Fong A, Tsuge M, Tabata T, Fang-Hoover J, Maidji E, Zydek M, Zhou Y, Inoue N, Loghavi S, Pepkowitz S, Kauvar LM, Ogunyemi D: Intrauterine growth restriction caused by underlying congenital cytomegalovirus infection. J Infect Dis 2014, 209:1573-1584

7. Pereira L, Maidji E, McDonagh S, Genbacev O, Fisher S: Human cytomegalovirus transmission from the uterus to the placenta correlates with the presence of pathogenic bacteria and maternal immunity. J Virol 2003, 77:13301-13314

8. Pereira L, Maidji E: Cytomegalovirus infection in the human placenta: maternal immunity and developmentally regulated receptors on trophoblasts converge. Curr Top Microbiol Immunol 2008, 325: 383-395

9. Enders G, Daiminger A, Bader U, Exler S, Enders M: Intrauterine transmission and clinical outcome of 248 pregnancies with primary cytomegalovirus infection in relation to gestational age. J Clin Virol 2011, 52:244-246

10. Stagno S, Pass RF, Cloud G, Britt WJ, Henderson RE, Walton PD, Veren DA, Page F, Alford CA: Primary cytomegalovirus infection in pregnancy: incidence, transmission to fetus, and clinical outcome. JAMA 1986, 256:1904-1908

11. Rosenthal LS, Fowler KB, Boppana SB, Britt WJ, Pass RF, Schmid SD, Stagno S, Cannon MJ: Cytomegalovirus shedding and delayed sensorineural hearing loss: results from longitudinal followup of children with congenital infection. Pediatr Infect Dis J 2009, 28:515-520

12. Mussi-Pinhata MM, Yamamoto AY, Moura Brito RM, de Lima Isaac M, de Carvalho e Oliveira PF, Boppana S, Britt WJ: Birth prevalence and natural history of congenital cytomegalovirus infection in a highly seroimmune population. Clin Infect Dis 2009, 49: $522-528$

13. Revello MG, Gerna G: Pathogenesis and prenatal diagnosis of human cytomegalovirus infection. J Clin Virol 2004, 29:71-83

14. Revello MG, Zavattoni M, Furione M, Baldanti F, Gerna G: Quantification of human cytomegalovirus DNA in amniotic fluid of mothers of congenitally infected fetuses. J Clin Microbiol 1999, 37: $3350-3352$

15. Gouarin S, Palmer P, Cointe D, Rogez S, Vabret A, Rozenberg F, Denis F, Freymuth F, Lebon P, Grangeot-Keros L: Congenital HCMV infection: a collaborative and comparative study of virus detection in amniotic fluid by culture and by PCR. J Clin Virol 2001, 21:47-55

16. Liesnard C, Donner C, Brancart F, Gosselin F, Delforge ML, Rodesch F: Prenatal diagnosis of congenital cytomegalovirus infection: prospective study of 237 pregnancies at risk. Obstet Gynecol 2000, 95:881-888

17. Antsaklis AJ, Daskalakis GJ, Mesogitis SA, Koutra PT, Michalas SS: Prenatal diagnosis of fetal primary cytomegalovirus infection. BJOG 2000, 107:84-88

18. Benirschke K, Kaufmann P: Pathology of the Human Placenta. New York, Springer, 2000, pp 616-636

19. Underwood MA, Gilbert WM, Sherman MP: Amniotic fluid: not just fetal urine anymore. J Perinatol 2005, 25:341-348

20. Buhimschi CS, Bhandari V, Hamar BD, Bahtiyar MO, Zhao G, Sfakianaki AK, Pettker CM, Magloire L, Funai E, Norwitz ER, Paidas M, Copel JA, Weiner CP, Lockwood CJ, Buhimschi IA: Proteomic profiling of the amniotic fluid to detect inflammation, infection, and neonatal sepsis. PLoS Med 2007, 4:e18

21. Buhimschi CS, Dulay AT, Abdel-Razeq S, Zhao G, Lee S, Hodgson EJ, Bhandari V, Buhimschi IA: Fetal inflammatory response in women with proteomic biomarkers characteristic of intra-amniotic inflammation and preterm birth. BJOG 2009, 116:257-267

22. Miki T, Lehmann T, Cai H, Stolz DB, Strom SC: Stem cell characteristics of amniotic epithelial cells. Stem Cells 2005, 23:1549-1559

23. Li H, Niederkorn JY, Neelam S, Mayhew E, Word RA, McCulley JP, Alizadeh H: Immunosuppressive factors secreted by human amniotic epithelial cells. Invest Ophthalmol Vis Sci 2005, 46:900-907

24. Hao Y, Ma DH, Hwang DG, Kim WS, Zhang F: Identification of antiangiogenic and antiinflammatory proteins in human amniotic membrane. Cornea 2000, 19:348-352

25. Keelan JA, Sato T, Mitchell MD: Interleukin (IL)-6 and IL-8 production by human amnion: regulation by cytokines, growth factors, glucocorticoids, phorbol esters, and bacterial lipopolysaccharide. Biol Reprod 1997, 57:1438-1444 
26. Gervasi MT, Romero R, Bracalente G, Erez O, Dong Z, Hassan SS, Yeo L, Yoon BH, Chaiworapongsa T: Midtrimester amniotic fluid concentrations of interleukin- 6 and interferon-gamma-inducible protein-10: evidence for heterogeneity of intra-amniotic inflammation and associations with spontaneous early $(<32$ weeks) and late $(>32$ weeks) preterm delivery. J Perinat Med 2012, 40:329-343

27. Scott GM, Chow SS, Craig ME, Pang CN, Hall B, Wilkins MR, Jones CA, Lloyd AR, Rawlinson WD: Cytomegalovirus infection during pregnancy with maternofetal transmission induces a proinflammatory cytokine bias in placenta and amniotic fluid. J Infect Dis 2012, 205:1305-1310

28. Tabata T, Petitt M, Puerta-Guardo H, Michlmayr D, Wang C, FangHoover J, Harris E, Pereira L: Zika virus targets different primary human placental cells, suggesting two routes for vertical transmission. Cell Host Microbe 2016, 20:1-12

29. Miki T, Mitamura K, Ross MA, Stolz DB, Strom SC: Identification of stem cell marker-positive cells by immunofluorescence in term human amnion. J Reprod Immunol 2007, 75:91-96

30. Revello MG, Baldanti F, Percivalle E, Sarasini A, De-Giuli L, Genini E, Lilleri D, Labo N, Gerna G: In vitro selection of human cytomegalovirus variants unable to transfer virus and virus products from infected cells to polymorphonuclear leukocytes and to grow in endothelial cells. J Gen Virol 2001, 82:1429-1438

31. Scrivano L, Sinzger C, Nitschko H, Koszinowski UH, Adler B: HCMV spread and cell tropism are determined by distinct virus populations. PLoS Pathog 2011, 7:e1001256

32. Pereira L, Hoffman M, Tatsuno M, Dondero D: Polymorphism of human cytomegalovirus glycoproteins characterized by monoclonal antibodies. Virology 1984, 139:73-86

33. Dondero DV, Pereira L: Monoclonal Antibody Production. Washington, DC, American Public Health Association, 1990, pp 101-124

34. Lilley BN, Ploegh HL, Tirabassi RS: Human cytomegalovirus open reading frame TRL11/IRL11 encodes an immunoglobulin G Fcbinding protein. J Virol 2001, 75:11218-11221

35. Navarro D, Paz P, Tugizov S, Topp K, La Vail J, Pereira L: Glycoprotein B of human cytomegalovirus promotes virion penetration into cells, transmission of infection from cell to cell, and fusion of infected cells. Virology 1993, 197:143-158

36. Nozawa N, Fang-Hoover J, Tabata T, Maidji E, Pereira L: Cytomegalovirus-specific, high-avidity $\operatorname{IgG}$ with neutralizing activity in maternal circulation enriched in the fetal bloodstream. J Clin Virol 2009, 46 Suppl 4:S58-S63

37. Zydek M, Petitt M, Fang-Hoover J, Adler B, Kauvar LM, Pereira L, Tabata T: HCMV infection of human trophoblast progenitor cells of the placenta is neutralized by a human monoclonal antibody to glycoprotein B and not by antibodies to the pentamer complex. Viruses 2014, 6:1346-1364

38. Enders G, Bader U, Lindemann L, Schalasta G, Daiminger A: Prenatal diagnosis of congenital cytomegalovirus infection in 189 pregnancies with known outcome. Prenat Diagn 2001, 21: $362-377$

39. Daiminger A, Bader U, Enders G: Pre- and periconceptional primary cytomegalovirus infection: risk of vertical transmission and congenital disease. BJOG 2005, 112:166-172

40. Gerna G, Sarasini A, Patrone M, Percivalle E, Fiorina L, Campanini G, Gallina A, Baldanti F, Revello MG: Human cytomegalovirus serum neutralizing antibodies block virus infection of endothelial/epithelial cells, but not fibroblasts, early during primary infection. J Gen Virol 2008, 89:853-865

41. Ross SA, Ahmed A, Palmer AL, Michaels MG, Sanchez PJ, Bernstein DI, Tolan RW Jr, Novak Z, Chowdhury N, Fowler KB, Boppana SB: Detection of congenital cytomegalovirus infection by real-time polymerase chain reaction analysis of saliva or urine specimens. J Infect Dis 2014, 210:1415-1418

42. Boppana SB, Ross SA, Shimamura M, Palmer AL, Ahmed A, Michaels MG, Sanchez PJ, Bernstein DI, Tolan RW Jr, Novak Z, Chowdhury N, Britt WJ, Fowler KB: Saliva polymerase-chain- reaction assay for cytomegalovirus screening in newborns. N Engl J Med 2011, 364:2111-2118

43. Boppana SB, Ross SA, Novak Z, Shimamura M, Tolan RW Jr, Palmer AL, Ahmed A, Michaels MG, Sanchez PJ, Bernstein DI, Britt WJ, Fowler KB: Dried blood spot real-time polymerase chain reaction assays to screen newborns for congenital cytomegalovirus infection. JAMA 2010, 303:1375-1382

44. Izumi M, Pazin BJ, Minervini CF, Gerlach J, Ross MA, Stolz DB, Turner ME, Thompson RL, Miki T: Quantitative comparison of stem cell marker-positive cells in fetal and term human amnion. J Reprod Immunol 2009, 81:39-43

45. Evron A, Goldman S, Shalev E: Human amniotic epithelial cells cultured in substitute serum medium maintain their stem cell characteristics for up to four passages. Int J Stem Cells 2011, 4:123-132

46. Lilleri D, Kabanova A, Revello MG, Percivalle E, Sarasini A, Genini E, Sallusto F, Lanzavecchia A, Corti D, Gerna G: Fetal human cytomegalovirus transmission correlates with delayed maternal antibodies to $\mathrm{gH} / \mathrm{gL} / \mathrm{pUL} 128-130-131$ complex during primary infection. PLoS One 2013, 8:e59863

47. Cui X, Lee R, Adler SP, McVoy MA: Antibody inhibition of human cytomegalovirus spread in epithelial cell cultures. J Virol Methods 2013, 192:44-50

48. Wang D, Li F, Freed DC, Finnefrock AC, Tang A, Grimes SN, Casimiro DR, Fu TM: Quantitative analysis of neutralizing antibody response to human cytomegalovirus in natural infection. Vaccine 2011, 29:9075-9080

49. Vanarsdall AL, Chase MC, Johnson DC: Human cytomegalovirus glycoprotein $\mathrm{gO}$ complexes with $\mathrm{gH} / \mathrm{gL}$, promoting interference with viral entry into human fibroblasts but not entry into epithelial cells. J Virol 2011, 85:11638-11645

50. Genini E, Percivalle E, Sarasini A, Revello MG, Baldanti F, Gerna G: Serum antibody response to the $\mathrm{gH} / \mathrm{gL} / \mathrm{pUL} 128-131$ five-protein complex of human cytomegalovirus (HCMV) in primary and reactivated HCMV infections. J Clin Virol 2011, 52:113-118

51. Vanarsdall AL, Ryckman BJ, Chase MC, Johnson DC: Human cytomegalovirus glycoproteins $\mathrm{gB}$ and $\mathrm{gH} / \mathrm{gL}$ mediate epithelial cellcell fusion when expressed either in cis or in trans. J Virol 2008, 82: $11837-11850$

52. Cui X, Meza BP, Adler SP, McVoy MA: Cytomegalovirus vaccines fail to induce epithelial entry neutralizing antibodies comparable to natural infection. Vaccine 2008, 26:5760-5766

53. Das S, Pellett PE: Spatial relationships between markers for secretory and endosomal machinery in human cytomegalovirus-infected cells versus those in uninfected cells. J Virol 2011, 85:5864-5879

54. Das S, Vasanji A, Pellett PE: Three-dimensional structure of the human cytomegalovirus cytoplasmic virion assembly complex includes a reoriented secretory apparatus. J Virol 2007, 81: 11861-11869

55. Sanchez V, Greis KD, Sztul E, Britt WJ: Accumulation of virion tegument and envelope proteins in a stable cytoplasmic compartment during human cytomegalovirus replication: characterization of a potential site of virus assembly. J Virol 2000, 74:975-986

56. Tandon R, AuCoin DP, Mocarski ES: Human cytomegalovirus exploits ESCRT machinery in the process of virion maturation. J Virol 2009, 83:10797-10807

57. Baldanti F, Paolucci S, Campanini G, Sarasini A, Percivalle E, Revello MG, Gerna G: Human cytomegalovirus UL131A, UL130 and UL128 genes are highly conserved among field isolates. Arch Virol 2006, 151:1225-1233

58. Hahn G, Revello MG, Patrone M, Percivalle E, Campanini G, Sarasini A, Wagner M, Gallina A, Milanesi G, Koszinowski U, Baldanti F, Gerna G: Human cytomegalovirus UL131-128 genes are indispensable for virus growth in endothelial cells and virus transfer to leukocytes. J Virol 2004, 78:10023-10033

59. Macagno A, Bernasconi NL, Vanzetta F, Dander E, Sarasini A, Revello MG, Gerna G, Sallusto F, Lanzavecchia A: Isolation of human monoclonal antibodies that potently neutralize human 
cytomegalovirus infection by targeting different epitopes on the gH/gL/UL128-131A complex. J Virol 2010, 84:1005-1013

60. Zhang L, Pagano JS: Structure and function of IRF-7. J Interferon Cytokine Res 2002, 22:95-101

61. Lin R, Heylbroeck C, Pitha PM, Hiscott J: Virus-dependent phosphorylation of the IRF-3 transcription factor regulates nuclear translocation, transactivation potential, and proteasome-mediated degradation. Mol Cell Biol 1998, 18:2986-2996

62. Sato M, Hata N, Asagiri M, Nakaya T, Taniguchi T, Tanaka N: Positive feedback regulation of type I IFN genes by the IFN-inducible transcription factor IRF-7. FEBS Lett 1998, 441:106-110

63. DeFilippis VR, Robinson B, Keck TM, Hansen SG, Nelson JA, Fruh KJ: Interferon regulatory factor 3 is necessary for induction of antiviral genes during human cytomegalovirus infection. J Virol 2006, 80:1032-1037

64. Taylor RT, Bresnahan WA: Human cytomegalovirus immediate-early 2 gene expression blocks virus-induced beta interferon production. J Virol 2005, 79:3873-3877

65. Adler B, Scrivano L, Ruzcics Z, Rupp B, Sinzger C, Koszinowski U: Role of human cytomegalovirus UL131A in cell type-specific virus entry and release. J Gen Virol 2006, 87:2451-2460

66. Siddiquee K, Zhang S, Guida WC, Blaskovich MA, Greedy B, Lawrence HR, Yip ML, Jove R, McLaughlin MM, Lawrence NJ, Sebti SM, Turkson J: Selective chemical probe inhibitor of Stat3, identified through structure-based virtual screening, induces antitumor activity. Proc Natl Acad Sci U S A 2007, 104:7391-7396

67. Ferrajoli A, Faderl S, Van Q, Koch P, Harris D, Liu Z, Hazan-Halevy I, Wang Y, Kantarjian HM, Priebe W, Estrov Z: WP1066 disrupts Janus kinase-2 and induces caspase-dependent apoptosis in acute myelogenous leukemia cells. Cancer Res 2007, 67:11291-11299

68. Kumar A, Bora U: Molecular docking studies on inhibition of Stat3 dimerization by curcumin natural derivatives and its conjugates with amino acids. Bioinformation 2012, 8:988-993

69. Fish KN, Soderberg-Naucler C, Mills LK, Stenglein S, Nelson JA: Human cytomegalovirus persistently infects aortic endothelial cells. J Virol 1998, 72:5661-5668

70. Dunn KC, Aotaki KA, Putkey FR, Hjelmeland LM: ARPE-19, a human retinal pigment epithelial cell line with differentiated properties. Exp Eye Res 1996, 62:155-169

71. Tugizov S, Maidji E, Pereira L: Role of apical and basolateral membranes in replication of human cytomegalovirus in polarized retinal pigment epithelial cells. J Gen Virol 1996, 77:61-74

72. Browne EP, Shenk T: Human cytomegalovirus UL83-coded pp65 virion protein inhibits antiviral gene expression in infected cells. Proc Natl Acad Sci U S A 2003, 100:11439-11444

73. Wendlandt EB, Graff JW, Gioannini TL, McCaffrey AP, Wilson ME: The role of microRNAs miR-200b and miR-200c in TLR4 signaling and NF-kappaB activation. Innate Immun 2012, 18:846-855

74. Wang FZ, Weber F, Croce C, Liu CG, Liao X, Pellett PE: Human cytomegalovirus infection alters the expression of cellular microRNA species that affect its replication. J Virol 2008, 82:9065-9074

75. O'Connor CM, Vanicek J, Murphy EA: Host microRNA regulation of human cytomegalovirus immediate early protein translation promotes viral latency. J Virol 2014, 88:5524-5532

76. Korpal M, Ell BJ, Buffa FM, Ibrahim T, Blanco MA, CeliaTerrassa T, Mercatali L, Khan Z, Goodarzi H, Hua Y, Wei Y, Hu G, Garcia BA, Ragoussis J, Amadori D, Harris AL, Kang Y: Direct targeting of Sec23a by miR-200s influences cancer cell secretome and promotes metastatic colonization. Nat Med 2011, 17:1101-1108

77. Sen N, Che X, Rajamani J, Zerboni L, Sung P, Ptacek J, Arvin AM: Signal transducer and activator of transcription 3
(STAT3) and survivin induction by varicella-zoster virus promote replication and skin pathogenesis. Proc Natl Acad Sci U S A 2012, 109:600-605

78. Faqing T, Zhi H, Liqun Y, Min T, Huanhua G, Xiyun D, Ya C: Epstein-Barr virus LMP1 initiates cell proliferation and apoptosis inhibition via regulating expression of Survivin in nasopharyngeal carcinoma. Exp Oncol 2005, 27:96-101

79. Wang Z, Luo F, Li L, Yang L, Hu D, Ma X, Lu Z, Sun L, Cao Y: STAT3 activation induced by Epstein-Barr virus latent membrane protein 1 causes vascular endothelial growth factor expression and cellular invasiveness via JAK3 and ERK signaling. Eur J Cancer 2010, 46:2996-3006

80. Gires O, Kohlhuber F, Kilger E, Baumann M, Kieser A, Kaiser C, Zeidler R, Scheffer B, Ueffing M, Hammerschmidt W: Latent membrane protein 1 of Epstein-Barr virus interacts with JAK3 and activates STAT proteins. EMBO J 1999, 18:3064-3073

81. Lu J, Verma SC, Murakami M, Cai Q, Kumar P, Xiao B, Robertson ES: Latency-associated nuclear antigen of Kaposi's sarcoma-associated herpesvirus (KSHV) upregulates survivin expression in KSHV-associated B-lymphoma cells and contributes to their proliferation. J Virol 2009, 83:7129-7141

82. Botto S, Streblow DN, DeFilippis V, White L, Kreklywich CN, Smith PP, Caposio P: IL-6 in human cytomegalovirus secretome promotes angiogenesis and survival of endothelial cells through the stimulation of survivin. Blood 2011, 117:352-361

83. Lepiller Q, Abbas W, Kumar A, Tripathy MK, Herbein G: HCMV activates the IL-6-JAK-STAT3 axis in HepG2 cells and primary human hepatocytes. PLoS One 2013, 8:e59591

84. Smith GB, Mocarski ES: Contribution of GADD45 family members to cell death suppression by cellular Bcl-xL and cytomegalovirus vMIA. J Virol 2005, 79:14923-14932

85. Yurochko AD, Mayo MW, Poma EE, Baldwin AS Jr, Huang ES: Induction of the transcription factor $\mathrm{Sp} 1$ during human cytomegalovirus infection mediates upregulation of the p65 and p105/p50 NFkappaB promoters. J Virol 1997, 71:4638-4648

86. Juckem LK, Boehme KW, Feire AL, Compton T: Differential initiation of innate immune responses induced by human cytomegalovirus entry into fibroblast cells. J Immunol 2008, 180:4965-4977

87. Yurochko AD, Kowalik TF, Huong SM, Huang ES: Human cytomegalovirus upregulates NF-kappa B activity by transactivating the NF-kappa B p105/p50 and p65 promoters. J Virol 1995, 69: $5391-5400$

88. Collins-McMillen D, Kim JH, Nogalski MT, Stevenson EV, Chan GC, Caskey JR, Cieply SJ, Yurochko AD: Human cytomegalovirus promotes survival of infected monocytes via a distinct temporal regulation of cellular Bcl-2 family proteins. J Virol 2015, 90: 2356-2371

89. Carlquist JF, Edelman L, Bennion DW, Anderson JL: Cytomegalovirus induction of interleukin-6 in lung fibroblasts occurs independently of active infection and involves a $G$ protein and the transcription factor, NF-kappaB. J Infect Dis 1999, 179:1094-1100

90. Iwamoto GK, Konicek SA: Cytomegalovirus immediate early genes upregulate interleukin-6 gene expression. J Investig Med 1997, 45: $175-182$

91. Terasaka Y, Miyazaki D, Yakura K, Haruki T, Inoue Y: Induction of IL-6 in transcriptional networks in corneal epithelial cells after herpes simplex virus type 1 infection. Invest Ophthalmol Vis Sci 2010, 51: 2441-2449

92. Reitsma JM, Sato H, Nevels M, Terhune SS, Paulus C: Human cytomegalovirus IE1 protein disrupts interleukin-6 signaling by sequestering STAT3 in the nucleus. J Virol 2013, 87:10763-10776 